Geological Society, London, Memoirs

\title{
Global Cambrian trilobite palaeobiogeography assessed using parsimony analysis of endemicity
}

J. Javier Álvaro, Per Ahlberg, Loren E. Babcock, Osvaldo L. Bordonaro, Duck K. Choi, Roger A. Cooper, Gappar KH. Ergaliev, I. Wesley Gapp, Mansoureh Ghobadi Pour, Nigel C. Hughes, James B. Jago, Igor Korovnikov, John R. Laurie, Bruce S. Lieberman, John R. Paterson, Tatyana V. Pegel, Leonid E. Popov, Adrian W. A. Rushton, Sergei S. Sukhov, M. Franco Tortello, Zhiyi Zhou and Anna Zylinska

Geological Society, London, Memoirs 2013, v.38; p273-296.

doi: 10.1144/M38.19

Email alerting service

Permission request

Subscribe click here to receive free e-mail alerts when new articles cite this article

click here to seek permission to re-use all or part of this article

click here to subscribe to Geological Society, London, Memoirs or the Lyell Collection

\section{Notes}




\title{
Chapter 19
}

\section{Global Cambrian trilobite palaeobiogeography assessed using parsimony analysis of endemicity}

\author{
J. JAVIER ÁLVARO ${ }^{1 *}$, PER AHLBERG ${ }^{2,3}$, LOREN E. BABCOCK $^{3}$, OSVALDO L. BORDONARO ${ }^{4}$, DUCK K. CHOI ${ }^{5}$, \\ ROGER A. COOPER 6 , GAPPAR KH. ERGALIEV ${ }^{7}$, I. WESLEY GAPP ${ }^{8}$, MANSOUREH GHOBADI POUR ${ }^{9}$, \\ NIGEL C. HUGHES ${ }^{10}$, JAMES B. JAGO ${ }^{11}$, IGOR KOROVNIKOV ${ }^{12}$, JOHN R. LAURIE ${ }^{13}$, BRUCE S. LIEBERMAN ${ }^{8}$, \\ JOHN R. PATERSON ${ }^{14}$, TATYANA V. PEGEL ${ }^{15}$, LEONID E. POPOV ${ }^{16}$, ADRIAN W. A. RUSHTON ${ }^{17}$, \\ SERGEI S. SUKHOV ${ }^{15}$, M. FRANCO TORTELLO ${ }^{18}$, ZHIYI ZHOU ${ }^{19}$ \& ANNA ŻYLIŃSKA ${ }^{20}$ \\ ${ }^{1}$ Centro de Astrobiología (INTA/CSIC), Ctra de Torrejón a Ajalvir, km 4, 28850 Torrejón de Ardoz, Spain
}

${ }^{2}$ Department of Earth and Ecosystem Sciences, GeoBiosphere Science Centre, Lund University, Sölvegatan 12, 22362 Lund, Sweden

${ }^{3}$ School of Earth Sciences, The Ohio State University, Columbus, OH 43210, USA

${ }^{4}$ IANIGLA-CONICET, c.c. 131, 5500 Mendoza, Argentina

${ }^{5}$ School of Earth and Environmental Sciences, Seoul National University, Seoul 151-747, Korea

${ }^{6}$ GNS Science - Te Pu Ao, 1 Fairway Drive, Avalon, PO Box 30368, Lower Hutt, New Zealand

${ }^{7}$ Institute of Geological Sciences, National Academy of Sciences, ul. Kabanbai Batyr 69a, 480100 Almaty, Republic of Kazakhstan

${ }^{8}$ Department of Geology and Natural History Museum/Biodiversity Research Center, University of Kansas, 1475 Jayhawk Blvd., 120 Lindley Hall, Lawrence, KS 66045, USA

${ }^{9}$ Department of Geology, Faculty of Sciences, Golestan University, Gorgan 49138-15739, Iran

${ }^{10}$ Department of Earth Sciences, University of California, Riverside, CA 92521, USA

${ }^{11}$ School of Natural and Built Environments, University of South Australia, Mawson Lakes, SA 5095, Australia

${ }^{12}$ Institute of Petroleum Geology and Geophysics, Siberian Branch of Russian Academy of Sciences, Academician Koptyug Avenue, 3, 630090 Novosibirsk, Russia

${ }^{13}$ Petroleum and Marine Division, Geoscience Australia, GPO Box 378, Canberra ACT 2601, Australia

${ }^{14}$ Division of Earth Sciences, School of Environmental \& Rural Science, University of New England, Armidale, NSW 2351, Australia

${ }^{15}$ Siberian Research Institute of Geology, Geophysics and Mineral Resources (SNIIGGiMS), Krasnyj Ave 67, 630091 Novosibirsk, Russia

${ }^{16}$ Department of Geology, National Museum of Wales, Cardiff, Cathays Park, Cardiff CF10 3NP, UK

${ }^{17}$ Palaeontological Department, The Natural History Museum, London SW7 5BD, UK

${ }^{18}$ División Paleontología Invertebrados, Museo de Ciencias Naturales, Paseo del Bosque s/n, 1900 La Plata, Argentina

${ }^{19}$ Nanjing Institute of Geology and Palaeontology, Chinese Academy of Sciences, 39 East Beijing Road, Nanjing 21008, China

${ }^{20}$ Faculty of Geology, University of Warsaw, Żwirki $i$ Wigury Str. 93, 02-089 Warszawa, Poland

*Corresponding author (e-mail: alvarobjj@cab.inta-csic.es)

\begin{abstract}
Palaeobiogeographical data on Cambrian trilobites obtained during the twentieth century are combined in this paper to evaluate palaeoceanographic links through $c .30 \mathrm{myr}$, once these arthropods biomineralized. Worldwide major tectonostratigraphic units are characterized at series intervals of Cambrian time and datasets of trilobite genera (629 for Cambrian Series 2, 965 for Cambrian Series 3, and 866 for the Furongian Series) are analysed using parsimony analysis of endemicity. Special attention is given to the biogeographical observations made in microcontinents and exotic terranes. The same is done for platform-basinal transects of well-known continental margins. The parsimony analysis of endemicity analysis resulted in distinct palaeogeographical area groupings among the tectonostratigraphic units. With these groupings, several palaeobiogeographical units are distinguished, which do not necessarily fit the previously proposed biogeographical realms and provinces. Their development and spatial distributions are broadly controlled by Cambrian palaeoclimates, palaeogeographical conditions (e.g. carbonate productivity and anoxic conditions) and ocean current circulation.
\end{abstract}

Supplementary material: Global dataset of Cambrian Epoch 2 (A), Cambrian Epoch 3 (B) and the Furongian Epoch (C) trilobite genera are provided at: http://www.geolsoc.org.uk/SUP18669

The main goal of the International Subcommission on Cambrian Stratigraphy (ISCS) is the development of an internationally applicable and unambiguous global chronostratigraphic chart for the Cambrian System. This chart will be useful for stratigraphic correlation internationally. One of the major challenges is resolving issues related to provincialism exhibited by fossil taxa, many of which have biostratigraphic utility. Among the mineralized macrofauna, the trilobites have been, and continue to be,

From: Harper, D. A. T. \& Servais, T. (eds) 2013. Early Palaeozoic Biogeography and Palaeogeography.

Geological Society, London, Memoirs, 38, 273-296. http://dx.doi.org/10.1144/M38.19

(C) The Geological Society of London 2013. Publishing disclaimer: www.geolsoc.org.uk/pub_ethics 
the most effective tool for large-scale chronostratigraphic and palaeobiogeographical analyses through much of the Cambrian. Only the lower series (Terreneuvian) and upper series (Furongian) of the four-fold Cambrian System have been defined by the ISCS and ratified by the International Union of Geological Sciences (IUGS) (Peng et al. 2004; Landing et al. 2007a; Peng \& Babcock 2008). The two series remaining to be defined are provisionally termed Cambrian Series 2 and 3.

Once they biomineralized, close to the beginning of Cambrian Epoch 2, the trilobites became an important and abundant group of benthic and pelagic metazoans with a preserved worldwide biogeographical distribution and distinct provinciality. Classical biogeographical analyses led to the subsequent subdivision of palaeocontinents into faunal realms, regions and provinces. These syntheses have been useful for a better understanding of the occurrence and disappearance of biogeographical barriers (commonly related to the rifting and drifting of major tectonostratigraphic units; e.g. Burrett \& Richardson 1980; Torsvik et al. 1996; Zhao et al. 1996; Kirschvink et al. 1997) and latitude- or depth-related thermal gradients (e.g. Palmer 1972; Cook \& Taylor 1975; Taylor \& Cook 1976; Babcock 1994a, b). However, during recent decades, a huge quantity of new trilobite data has been published, and this has made delineation of biogeographical boundaries increasingly difficult. Quantitative, computer-based methods for analysing the spatial and temporal distribution of Cambrian trilobites have taken on a larger role in recent biogeographical studies.

The aim of this paper is to provide an updated synthesis of the biogeographical distribution of Cambrian trilobites according to tectonostratigraphic units that have yielded biogeographically significant faunas. The current revision is based on a global database of Cambrian trilobites (up to September 2010), with genera organized by family and the various palaeogeographical units or stations. The database employed in this paper was summarized by the authors and is provided as Supplementary material. The concepts of previously defined realms, regions, provinces and their transitions are revised in light of this analysis.

\section{Representative palaeogeographical units}

The Cambrian palaeobiogeographical terminology has often been used indiscriminately in publications concerning palaeogeographical reconstructions and plate-tectonic configurations. The confusion of palaeogeographical and biogeographical terms has commonly led to a mixing of terminology and palaeo(bio)geographical concepts, which are separated below. The different tectonostratigraphic units in which the global dataset of Cambrian trilobite genera (see Supplementary material) are grouped are discussed in this section.

\section{Baltica}

Baltica (BA in Fig. 19.1) consisted of a major part of northern Europe. It was bounded on the west by the Iapetus suture, on the east by the Ural suture, on the south by the Variscan suture, and on the SW by a suture located close to, but not quite along, the Teisseyre-Tornquist Zone. According to Cocks \& Torsvik (2002, 2005), Baltica included the southern Małopolska and northern Łysogóry terranes of the Holy Cross Mountains, Poland, as well as Novaya Zemlya and the Ukraine. Palaeomagnetic data (Torsvik \& Rehnström 2001) indicate that Baltica was geographically inverted (present-day southern Baltica formerly faced north, towards the equator and NW Baltica the NW Gondwanan margin) and lay at temperate-subtropical palaeolatitudes (c. 30$60^{\circ} \mathrm{S}$ ) during Cambrian times. Laurentia and present-day western Baltica, as well as Laurentia and West Gondwana, were separated by the Iapetus Ocean, while the Ægir Sea separated eastern Baltica from the Taimyr region of Siberia. During the Cambrian, Baltica probably moved eastwards along the Gondwanan margin, and by $c$. 515-520 Ma subduction in the Ægir Sea was initiated. A major event is recognized in Furongian-Early Ordovician times (c. 500-478 Ma) when Baltica must have undergone a $55^{\circ}$ anticlockwise rotation within $c$. 22 myr, related to the early Caledonian Finnmarkian Orogeny, which involved arc-continent collision following subduction. In this paper, Baltica is subdivided into two tectonostratigraphic domains, based on facies associations and the composition of the Cambrian trilobite faunas: (1) an inner-platform sector located in southeastern Norway and southern and central Sweden (e.g. Scania, Västergötland, Östergötland, Närke, Öland and Jämtland); and (2) an outer platformto-basin sector represented by the Holy Cross Mountains in Poland and the Digermul Peninsula in northern Norway.

The successions predominantly consist of siliciclastic deposits, which accumulated under generally shallow to moderately deep conditions. Terreneuvian and Series 2 strata are largely represented by sandstones and siltstones, whereas Series 3 and the Furongian are dominated by mudstones and shales. In Scandinavia, these argillaceous deposits form part of the Alum Shale Formation, a succession of dark grey to black, organic-rich shales with concretionary carbonate lenses (stinkstones or orsten) and a few limestone beds. The Alum Shale Formation is highly condensed and was formed under stable tectonic and poorly oxidized (dysoxic to anoxic) conditions. To the east, the Alum Shale facies grades into coarser siliciclastic deposits with several gaps in the succession (Nielsen \& Schovsbo 2006).

\section{Laurentia}

Laurentia (LA) included major parts of the North American craton, Greenland, NW Ireland, Scotland and the Chukotks Peninsula in NE Russia (Fig. 19.1). Major areas of Cambrian outcrop along the margins of modern North America that are excluded from the Laurentian palaeocontinent are terranes in western Alaska and Avalonian terranes in the Appalachian region. Regions exposing fossiliferous Cambrian strata are widely distributed across the Laurentian continent, and consist of two belts of siliciclastic facies, the inner and outer detrital belts, which were separated by an extensive carbonate platform. During highstand in the Furongian, Cambrian oceans lapped far onto the cratonic interior. As a result, most North American states and provinces have a record of Cambrian rocks that are either exposed at the surface or sampled in core.

The breakup of the Neoproterozoic supercontinents Rodinia and later Pannotia at $c$. $570 \mathrm{Ma}$ led to a rapid northward movement of Laurentia from a high southerly latitude to an equatorial position towards the end of the Ediacaran (c. $550 \mathrm{Ma})$, associated with the opening of the Iapetus Ocean. During the Cambrian, Laurentia moved eastwards across the equator and was oriented about $90^{\circ}$ clockwise from the present-day North American position, with its Cordilleran margin at lower latitudes than its south-facing Atlantic margin (Hodych et al. 2004). During intervals of the Cambrian, the Laurentian craton was encircled by three lithofacies belts (Palmer 1972; Robison 1976): (1) a siliciclastic-dominated, open-ocean-facing outer platform; (2) a carbonate belt that included reef buildups at times; and (3) a siliciclastic-dominated inner shelf. Trilobite biofacies on the craton mirrored lithofacies patterns, and the carbonate belt restricted marine circulation and trilobite dispersal to various extents through Cambrian time. Many polymerid trilobites that inhabited the Laurentian craton were endemic, although most agnostoids present in open shelf facies were intercontinentally distributed. As a tropically located continent, water masses in deep shelf areas were stratified by temperature or other factors that covaried with depth (Cook \& Taylor 1975; Taylor \& Cook 1976; Babcock 1994a, b). For this reason, some deep-shelf-dwelling trilobite genera were intercontinentally 


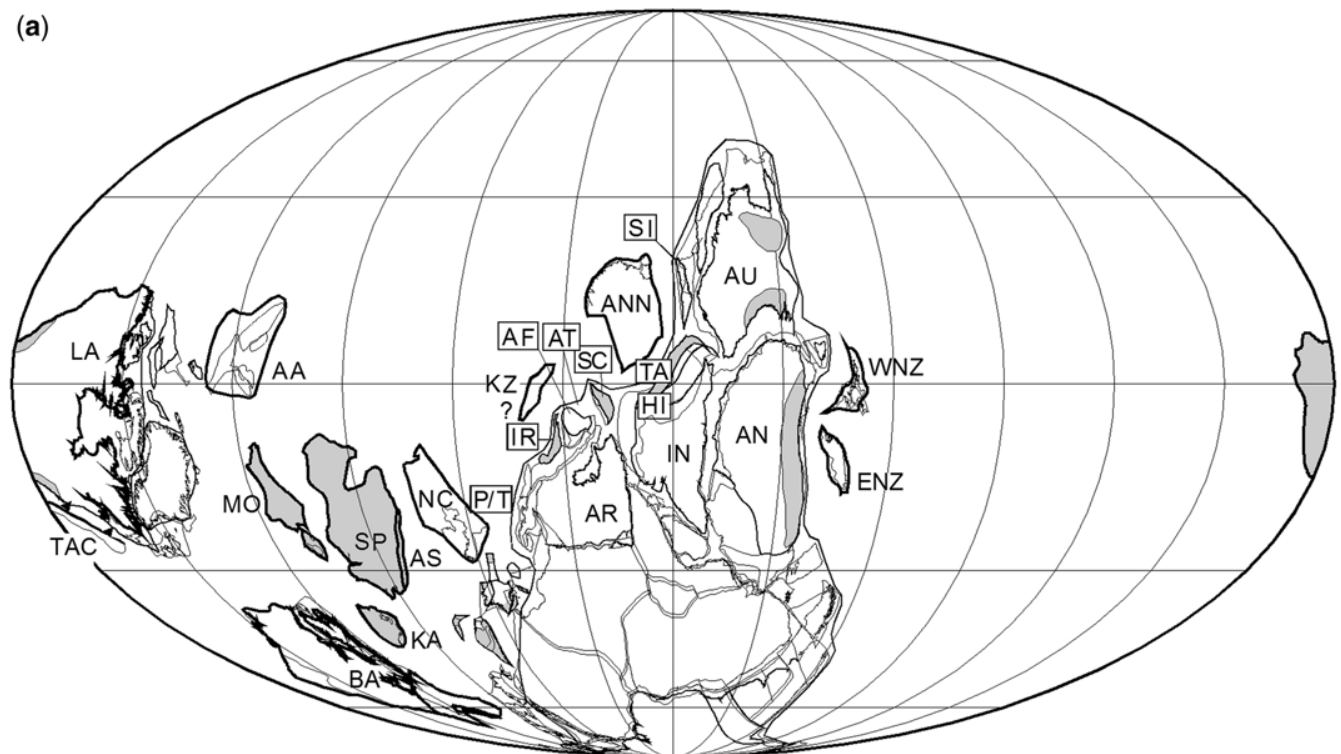

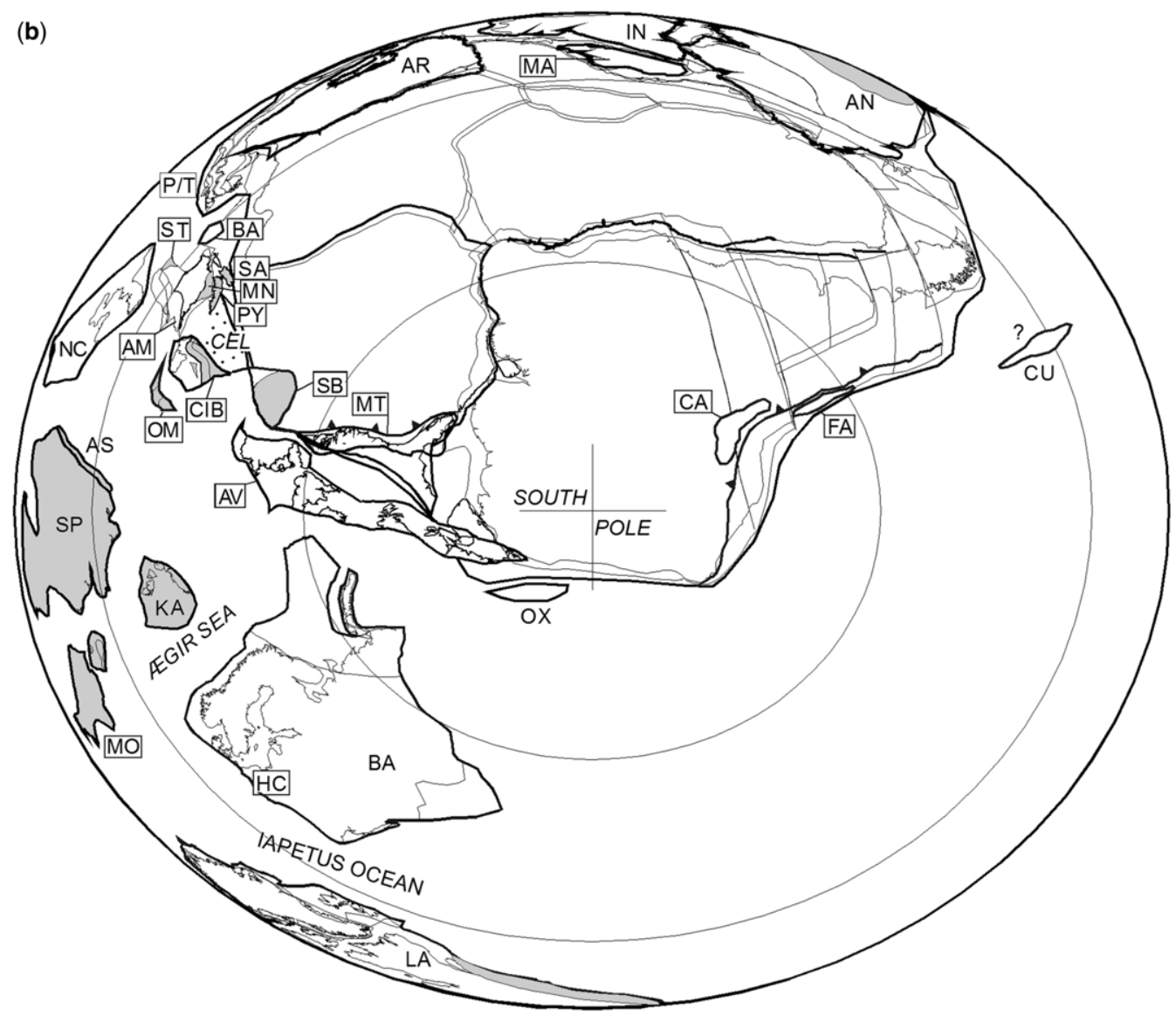

Fig. 19.1. Tentative palaeogeographical reconstruction of the Cambrian palaeocontinents, microcontinents and terranes reported in the text, showing the subtropical setting of archaeocyathan-bearing reefs (grey area); modified from Sánchez-Zavala et al. (1999), Torsvik et al. (2009), Álvaro et al. (2000, 2007) and Cocks \& Torsvik (2002). AA, Arctic Alaska/Chukotks; AF, Afghanistan; AM, Armorican Massif; AN, Antarctica; ANN, Annamia; AR, Arabia; AS, AltaiSayan foldbelt; AT, Alai terrane; AU, Australia; AV, Avalonia; BA, Baltica; CA, Cordillera Oriental (Argentina); CEL, Cantabro-Ebroan land area; CIB, Cantabro-Iberian basin; CU, Cuyania; ENZ, Eastern New Zealand; FA, Famatina; HC, Holy Cross Mountains; HI, Himalayan terranes; IN, India; IR, Iran; IN, India; KA, Kara terrane; KZ, Kazakhstan; LA, Laurentia; MA, Madagascar; MN, Montagne Noire; MO, Mongolia; MT, Mauritanides; NC, North China (Sino-Korean block); OX, Oaxaquia; OM, Ossa-Morena; P/T, Pontides/Taurides (Turkey); PY, Pyrenees; SA, Sardinia; SB, Souss basin (Morocco); SC, South China (Yangtze block); SI, Sibumasu; SP, Siberian Platform; ST, Saxo-Thuringia; TA, Tarim; TAC, Taconic Belt (in its Ordovician position as its peri-Gondwanan provenance is still under discussion); and WNZ, West New Zealand. distributed, especially in inferred cool-water facies. The trilobite database reported below corresponds to all of Laurentia and ignores subtleties of intra-continent biofacies, as biogeographical differences within the macrocontinent are nowhere near as significant as those between Laurentia and other biogeographical regions.

\section{Siberia}

We follow Rundqvist \& Mitrofanov's (1993) proposal, which included in Siberia the Siberian Platform (SP) and most of the
Baikalides. The Baikalides accreted onto the main craton in Neoproterozoic times. Siberia was bounded on the west by the Urals and the Irtysh foldbelts, on the south by the Amurian (Mongolian) terranes and ophiolitic belts, and on the northeast by the Verkhoyansk foldbelt. The southern and southwestern boundaries of the ancient Siberian craton (in contemporary coordinates) are at present marked by large sutures; for example, the Baikal-Patom terrane is separated from Siberia by one such suture, which makes it difficult to determine its Cambrian palaeogeographical position (Seslavinsky \& Maidanskaya 2001). The EdiacaranCambrian succession of the Kolyma Uplift is characterized by fossils and facies typical of the Yudoma-Olenek Basin of the 
Siberian Platform (Tkachenko et al. 1987) Thus, Kolyma was probably a part of Siberia at least during the Ediacaran-Cambrian. At that time, the northern Taimyr was not yet part of Siberia, and was separated from the Siberian craton by an oceanic basin of unknown width (Khain \& Seslavinsky 1995). Cambrian rocks in present-day Siberia are exposed on the Siberian Platform (East Siberia), the Altai-Sayan area (southern West Siberia) and the Kara terrane.

Siberian Platform. The Siberian Platform (SP) is bordered on the west by the Yenisei ridge, on the north by the Taimyr folded zone, on the east by the Verkhoyansk folded system, and on the south by the Baikal and Eastern Sayan mountain systems. The Siberian Platform is characterized by a thick $(>2 \mathrm{~km})$ Cambrian succession, which displays a distinct facial zonation with halogen-carbonate, carbonate and black shale-flyschoid complexes substituting for one another from the southwest to the northeast of the platform. During the Cambrian, Siberia was located in tropical palaeolatitudes (oriented $180^{\circ}$ from its present alignment) with enduring and relatively slow basement subsidence, and irregular sediment accumulation.

During the late Terreneuvian and early Epoch 2 (Tommotian and Atdabanian ages of traditional Siberian usage), the Siberian Platform was covered by shallow epeiric seas subdivided into an inner shelf (mainly the southwestern part) and an open, outer shelf. Pioneer carbonate buildups and banks originated both at shoals, confined to palaeohighs corresponding to the modern NepoBotuoba and Baikit anticlines, within the inner salt-rich shelf, and along the transitional area to the open shelf. Palaeogeographically widespread and thick carbonate platforms with reef-rim systems in the inner part of the craton and starved basins ( $1 \mathrm{~km}$ or deeper) along the craton margin were formed through the Cambrian Epoch 2 (Botoman Age) till the early part of Epoch 3 (Amgan Age). The carbonate platforms transformed into subaerial plains at the beginning of the Drumian Age. In the Furongian, almost the entire carbonate platform was covered by shallow seas, being emergent at times. Distinctions of the lithological composition and faunal characteristics of Cambrian strata from the southwestern part of the craton and those from the eastern and northwestern parts of the craton, as well as specific patterns of the so-called 'transition zone' that separates these two areas were widely remarked (Khomentovsky \& Repina 1965; Savitsky et al. 1972; Kirkinskaya \& Trunov 1975; Pisarchik et al. 1975; Chechel et al. 1977; Savitsky \& Astashkin 1979; Anon. 1983; Astashkin et al. 1984, 1991; Rozanov \& Sokolov 1984; Kokoulin \& Rudavskaya 1985; Mel'nikov et al. 1989; Repina \& Rozanov 1992; Pegel \& Sukhov 1996).

Altai-Sayan area. The Altai-Sayan area (AS) is situated among accretionary zones that were a part of the central Asian foldbelt, nowadays located between the Siberian Platform and Cathaysia (southeastern terranes of South China) and uniting Riphean, Salairian, Caledonian, Variscan and Indo-Sinian zones. The accretionary zones were formed in marginal parts of the Palaeoasian Ocean, being gradually moved through time into its centre. It is most evident at the southwestern edge of the Siberian palaeocontinent to which the Neoproterozoic eastern-Sayan accretionary folded zone was first accreted. Later, in Cambrian Epoch 2 to Furongian (Salairian), the Cambrosayan accretionary folded area (western Eastern Sayan), Kuznetsk Alatau, Tuva, western and northern Mongolia, and Buryatiya were added; to which, during the Late Ordovician, a vast accretionaty massif, incorportating Mountain and Mongolian Altai, central and a part of southern Mongolia, was attached. It was terminated by the formation of late Silurian accretionary folded zones at the places of residual depressions of Salair and Western Sayan (Mossakovsky et al. 1993). By the end of Cambrian Epoch 3, accretion of the Altai-Sayan, Mongolia and Baikal-Patom regions had mostly ended and the constituent fragments were added to Siberia (Seslavinsky \& Maidanskaya 2001). This collision led to formation of an elongate semicircular orogenic belt around Siberia, from Salair to Transbaikalia. Rugged mountain relief was formed there, and extensive molasse deposits developed (Kremenetskiy \& Dalmatov 1988; Astashkin et al. 1995; Kheraskova 1995). During Cambrian Epoch 2, the AltaiSayan area had stable biogeographical communications with the Siberian Platform (58 trilobite genera in common) and central Asia (30 trilobite genera in common). As a whole, wide connections were ensured by the shared presence of miomerid calodiscids, hebediscids and weymouthiids, and polymeroid ellipsocephalids, known also in Baltica and Gondwana. Antagmids, chengkouaspids, dorypygids, eodiscids and ptychopariids linked Siberia with Laurentia and East Gondwana. The redlichiids were of importance in biogeographical connections of the Altai-Sayan basin with East Gondwana.

Tuva, located in the southeast Altai-Sayan area, was somewhat isolated from neighbouring regions. Its trilobite assemblages reflect intermittent biogeographical contacts: moderate in late Atdabanian and middle Botoman when the proportion of endemic Altai-Sayan species reached 47\%, and extremely weak in early Botoman and late Toyonian when Tuvinian species made up more than $75 \%$ of the trilobite assemblages. Tuva showed far less biogeographical connections with eastern Siberia.

During Cambrian Epoch 3, biogeographical communications of Altai-Sayan expanded considerably. As before, the relationship with the Siberian Platform was the closest ( 72 trilobite genera in common). Links were considerably strengthened with Kazakhstan and China (more than 30 genera shared among each of these regions), Baltica (25 genera), Laurentia (24 genera, Australia (34 genera) and Antarctica (seven genera, compared to one genus in Cambrian Epoch 2). Communications with central Asia and the Mediterranean and Avalonian regions remained at the former level. New links with the Precordillera, Himalaya and Iran arose. The communications with the Baikal area and the Russian Far East were somewhat reduced, and the contacts with the Taconic Belt were interrupted. Assemblages of ceratopygids, diplagnostids, eodiscids and ptychagnostids reflect communication of the AltaiSayan area with Baltica, Laurentia, and East and West Gondwana. In addition, the link between Laurentia and Gondwana is represented by common dolichometopids, oryctocephalids, peronopsids, and ptychopariids. The clavagnostids, corynexochids and solenopleurids had similar importance in contacts with Baltica and Gondwana. The papyriaspidids, which occur in the Altai-Sayan area, were typical of East Gondwana, as well as the paradoxidids of Baltica and West Gondwana.

During the Furongian, free biogeographical communications of Altai-Sayan and the Siberian Platform (49 trilobite genera in common) remained. Contacts with Kazakhstan (32 genera), China (26 genera), Antarctica (six genera) and the Mediterranean region (six genera) kept approximately the same level. The numbers of shared genera with Baltica (16), Laurentia (18), Precordillera (seven), Australia (20) and Avalonia (12) became slightly reduced. Contacts with central Asia remained much weakened, with only two shared trilobite genera (Homagnostus and Pseudagnostus). Communications with the Russian Far East and the Baikal area ceased. There were possible weak contacts between the AltaiSayan area and the Taconic Belt (Lotagnostus), Iran (Stigmatoa), Afghanistan (Pseudagnostus) and the Himalaya (Damesella).

Communication of the Altai-Sayan area with the Siberian Platform, Baltica, Laurentia and Gondwana was established by agnostid, diplagnostid, elviniid, glyptagnostid and olenid taxa. In addition, representatives of some other families represent other biogeographical links: ammagnostids, aphelaspidids, catillicephalids (connection with Laurentia and mainly East Gondwana), ceratopygids, clavagnostids (connection with Baltica and mainly East Gondwana), damesellids and eulomids (main connection with East Gondwana).

Kara terrane. Outboard of Siberia is the Kara terrane (KA), which includes Severnaya Zemlya and northern Taimyr. Trilobites 
typical of northwestern Siberia have been recorded, together with genera known from Baltica and South China (Lazarenko 1982; Rushton et al. 2002).

\section{West Gondwana}

Following Vaughan \& Pankhurst's (2008) revision, West Gondwana is herein considered as part of the homonomous supercontinent represented today by South America, Arabia (AR), Africa, the Mediterranean region and West Antarctica (Fig. 19.1). However, this definition is over-simplified and reflects a subdivision based on the breakup rather than the amalgamation and configuration of the supercontinent. The boundary with East Gondwana consists of a meandering zone of late Neoproterozoic-Terreneuvian orogenic and mobile belts, termed the pan-African Belt, that extended from and included the Arabian-Nubian shield in the north down to Antarctica (AN) in the south. The oceanic sector of West Gondwana is subdivided below into those margins that contain Cambrian trilobite-bearing strata, which are, from southwest to northeast: South America, some central American (e.g. Oaxaquia; OX) and North American (Carolinia, Avalonia and Meguma) terranes, the western and eastern Mediterranean regions, and central Europe. During the Cambrian, West Gondwana drifted polewards, crossing subtropical and temperate palaeolatitudes of the Southern Hemisphere, which directly influenced the style of sedimentation and resulted in climate-sensitive facies of palaeosols, limestones and evaporates (Scotese et al. 1999; Álvaro et al. 2000).

South America. Three major palaeogeographical units are distinguished in South America: the Cordillera Oriental (CA), the Famatina System (FA) and the Precordillera (or Cuyania, CU) terrane. The Cordillera Oriental of NW Argentina is an elongated geomorphologic unit extending through Jujuy and Salta provinces. It comprises a set of north-south-trending mountains (e.g. Santa Victoria, Zenta, Aguilar, Tilcara and Chañi) separated by deep valleys, that constitute a prominent east-verging thrust system (e.g. Astini 2008). Exposures of Neoproterozoic metasedimentary rocks and lower Palaeozoic cover are most representative, followed by Devonian-Carboniferous (glacifluvial and marine) and Cretaceous-Neogene (mostly continental) deposits. The metasedimentary basement of the Cordillera Oriental consists of Neoproterozoic-Terreneuvian sandstones, shales and conglomerates (Puncoviscana Formation s.l.), which have yielded a wide variety of ichnofossils. Overlying this basement, the Mesón Group (Cambrian Series 3) is represented by quartzites and subordinate shales with abundant shallow marine ichnotaxa. The oldest trilobite-bearing strata are recognized in uppermost FurongianOrdovician siliciclastic units (e.g. Santa Victoria Group and equivalents; Harrington \& Leanza 1957; Benedetto 2003; Moya 2008), which record the infill of a retroarc basin (Buatois \& Mángano 2003; Buatois et al. 2006; Astini 2008).

The Famatina System of NW Argentina is another elongated unit along the Catamarca, La Rioja and northern San Juan provinces, characterized by Ordovician volcanism. It comprises a set of mainly north-south-trending ranges (e.g. Las Planchadas, Narváez, Famatina, Paimán, Sañogasta, Paganzo and Cerro Blanco), which are delimited in the east and in the west by broad valleys. The basement of the Famatina System is represented by a passive margin sequence that was metamorphosed to low-grade during Neoproterozoic-Cambrian Epoch 3 times. Overlying this basement, latest Furongian trilobites are recorded in shelf marls and shales of the lower Volcancito Formation. In the Floian Stage, a voluminous series of fossiliferous deposits accumulated contemporaneously with active volcanic episodes, and these were subsequently cut by Middle-Upper Ordovician granitoids. The volcanosedimentary complex is interpreted as related to subduction, and the granitic and volcanic rocks together represent a continental magmatic arc developed regionally during the Early Ordovician. The stratigraphy of the Famatina Basin also comprises upper Palaeozoic sedimentary strata with plutonism, and Cenozoic synorogenic successions and volcanics (Astini 2003).

Finally, the Precordillera (Astini et al. 1995) or Cuyania terrane (Ramos 2004) is a part of the Precordillera Range of western Argentina. It consists of a north-south-trending mountainous area, at least $300 \mathrm{~km}$ long and $<100 \mathrm{~km}$ wide. The most significant feature of the fossiliferous Cuyanian strata is a change from a Cambrian brachiopod and trilobite fauna of Laurentian affinity to a Middle-Late Ordovician Gondwanan fauna (Astini et al. 2004; Bordonaro et al. 2008). The Cuyania terrane has been interpreted both as a rifted piece of Laurentia, which accreted to the protoAndean margin of Gondwana in the Middle-Late Ordovician, and as a peri-Gondwanan margin (Finney 2007). Trilobites erected and recognized by Rusconi, Leanza and Poulsen are under revision.

Quite distinct is a small fauna from Colombia, which is representative of the Cambrian Series 3 and includes a species of Paradoxides s.l. (Rushton 1963). This is compatible with the proximity of Avalonia, as shown in Figure 19.1, or may represent part of a small terrane outboard of South America, such as the Oaxaquia terrane.

Central American terranes. In Mexico, peri-Gondwanan terranes make up the Oaxaquia (OX) and the Maya terranes (the Yucatan block), and include also the Chortis block of Honduras and Guatemala (Sánchez-Zavala et al. 1999; Nance et al. 2008). In Sonora (Oaxaquia; Ortega-Gutiérrez et al. 1995) the complex Proterozoic basement of Mexico is unconformably overlain by FurongianLower Ordovician strata that contain trilobites of Gondwanan affinity (Robison \& Pantoja-Alor 1968; Shergold 1975). Conodonts indicate that the trilobite-bearing Yudachica Member of the Tinú Formation is late Furongian in age (Landing et al. 2007b).

North American terranes. The peri-Gondwanan terranes of North America now occupy much of the eastern flank of the Appalachian Orogen, where they include West Avalonia, Ganderia, Meguma and Carolina, and the Suwanee terrane of the Florida subsurface. Although Cocks \& Torsvik (2002) and Cocks \& Fortey (2009) suggested ignoring palaeogeographical differences between eastern and western Avalonia (AV), this unit is still currently subdivided into West Avalonia (New England and Atlantic Canada) and East Avalonia (southern Britain, the subsurface of the Brabant Massif of Belgium, the Rhenish Massif of NW Germany and, probably, the Moravo-Silesian Zone-Brunovistulian of the Bohemian Massif). Some Cambrian palaeogeographical models place Avalonia as attached to West Gondwana (and subsequently detached during the Early Ordovician; Cocks \& Torsvik 2002) or as a separate microcontinent (Landing 2005).

Outboard of Avalonia in the northern Appalachians lies the Meguma terrane, which is exposed only in Nova Scotia but extends oceanwards to the edge of the continental shelf from the Grand Banks to Cape Cod. It is separated from Avalonia by the Minas fault zone, a major late Palaeozoic strike-slip boundary. The oldest rocks are those of the Meguma Group, a thick $(>10 \mathrm{~km})$ ? Neoproterozoic-Lower Ordovician succession of turbiditic sandstones and overlying shales. A peri-Gondwanan affinity of its sparse trilobite fauna was suggested by Pratt \& Waldron (1991).

Another terrane is represented in the Appalachian Belt by thin (locally $<600 \mathrm{~m}$ ), Cambrian-Lower Ordovician successions in New York and Quebec. The so-called Taconic Belt or allochthon (TAC) includes Terreneuvian rift strata, overlain by passivemargin slope deposits, and synorogenic rocks of the MiddleLate Ordovician Taconic Orogeny.

The western margin of present-day North America is composed of numerous terranes that are of diverse origins, ranging from Laurentian-associated to extra-Laurentian. Some terranes contain 
Cambrian strata and trilobites. Perhaps most significant among them is the Nixon Fork terrane of Alaska, which yields trilobites with a predominantly Siberian biogeographical affinity (St John \& Babcock 1997).

Western Mediterranean region. The Variscan regions of southern and central Europe (named below Cadomia, Iberia and Bohemia) have been previously grouped in the so-called Armorican microplate, which presumably detached from West Gondwana during part of the Palaeozoic and apparently had an independent latitudinal evolution. However, a critical review made by Robardet (2003) has shown that the existence of this putative microplate cannot be considered well established. Biogeographic, palaeoclimatic and facies arguments suggest that the southern and central European regions remained in close connection with Gondwana. Robardet (2003) argued cogently that the Armorican microplate did not exist. For this reason, the concept of Armorica is not recognized in this paper.

Cambrian strata of the Moroccan Atlas are present in the Anti-Atlas and central High Atlas mountains. There are also scattered inliers in the Jebilet, Rehamna and coastal Meseta regions. The Souss Basin (SB) (Geyer et al. 1995) was filled with Ediacaran-Carboniferous sediments throughout the Anti-Atlas and southern High Atlas, the northern boundary of which is placed along the South Atlas fault, whereas the northern limit of the craton is situated along the Anti-Atlas major fault, where several pan-African ophiolitic complexes are preserved (Ennih \& Liégeois 2008). During the Cambrian, the Souss basin was a broad shallow epeiric sea, influenced by a phase of intracratonic, multistage rift. The rifting activity propagated from the intracratonic Anti-Atlas to the turbiditic Coastal Meseta, where it progressively aborted at the beginning of the Furongian (Álvaro et al. 2008).

The pre-Variscan exposures of Iberia are traditionally subdivided into four tectonostratigraphic zones called the Cantabrian, West Asturian-Leonese, Central Iberian and Ossa-Morena zones. Their evolution has been interpreted in terms of two distinct troughs: the Ossa-Morena (OM) and Cantabro-Iberian (CIB) basins, the latter comprising some inliers, such as the Demanda Sierra and the Iberian Chains. The Cantabro-Iberian basin was limited to the northeast by the Cantabro-Ebroan land area (CEL), to the north of which a mosaic of Cambrian platforms are preserved in the Pyrenees (PY), Montagne Noire (southern Central Massif, France; MN) and Sardinia (Italy; SA). In the OssaMorena Zone, rifting propagated diachronously across the OssaMorena Zone from the Terreneuvian to the Late Ordovician, postdating an episode of Neoproterozoic-Terreneuvian accretion of a continental arc (Cadomian orogeny; Sánchez-García et al. 2003; Etxebarría et al. 2006). Similar Ediacaran-Cambrian Series 2 successions, recording Cadomian and pan-African orogenies succeeded by rifting, have been recorded in the North Armorican Cadomian Belt, Saxo-Thuringia, and the Meseta and Atlas mountains, all of which were seemingly situated in the same palaeogeographical West African peri-Gondwanan region of the AvalonianCadomian active margin (Doré 1994; Pereira et al. 2006).

Saxo-Thuringia and Bohemia. According to Havlíček et al. (1994), the German and Barrandian (an area situated in the central part of the Bohemian Massif), lower Palaeozoic successions belong to the Perunica terrane. This crustal segment is considered a separate microplate occupying the major part of the Bohemian massif, and involving the Moldanubian, Barrandian and SaxoThuringian (Saxothuringian-Lugian) zones' (Havlíček et al. 1994). Subsequently, Linnemann et al. (2000) revised the concept of Perunica, excluding Saxo-Thuringia; they distinguished the Brittany-Normandy, Perunica and Saxo-Thuringia terranes, which would form the so-called 'Armorican Terrane collage' (subsequently rejected by Robardet 2003). Two tectonostratigraphic areas are considered below: the Bohemian (or Barrandian, BR) and Saxo-Thuringian (ST) units. The latter comprises a fault-bounded crustal fragment with Cambrian outcrops in the Doberlug Syncline, Thuringia and the Franconian Forest area. The Barrandian area corresponds to the Př́bram-Jince Basin, where a thick Terreneuvian-Cambrian Series 2 continental succession is covered by Series 3 transgressive marine fossiliferous shales (the Jince Formation) and Furongian volcaniclastic complexes. Laterally, the Jince Formation crops out in the SkryjeTyřovice area. Owing to close biogeographical affinities (Álvaro et al. 1999, 2003a), Cambrian trilobites of the Skryje-Tyřovice area and the Príbram-Jince Basin (both belonging to the Barrandian of Bohemia) will be reported in the same dataset as SaxoThuringia.

Eastern Mediterranean region. The Pontides of Turkey are considered a Variscan terrane, separated from the Anatolide-Tauride block and the Arabian Platform, by the Tethyan Izmir-AnkaraErzincan suture (Okay et al. 2008). The Anatolide-Tauride Platform, unaffected by the Variscan Orogeny, formed a part of the eastern Mediterranean region of West Gondwana. Cambrian facies associations and trilobite faunas are close to those of the Iberian Peninsula, Montagne Noire and Sardinia (Dean et al. 1981, 1993; Dean \& Monod 1997; Álvaro et al. 1999, 2003a). The Pontides are considered as a terrane located to the west of the Taurides (Dean et al. 2000), although their Cambrian trilobite faunas cannot be differentiated from those of the Taurides. Here, they are treated together as Pontides/Taurides $(\mathrm{P} / \mathrm{T})$.

The Cambrian of the easternmost Mediterranean region is known from a few exposures in Jordan and Israel, and constitutes a palaeogeographical link with the Arabian Platform. The Ediacaran-Cambrian transition and the Cambrian are represented by intracratonic syn-rift and post-rift successions. Graben and horst structures produced by rifting through the extensional phase of the pan-African Orogeny extend across West Gondwana and North Africa to the Middle East (Amireh et al. 2008).

\section{East Gondwana}

Relics of East Gondwana containing Cambrian trilobite-bearing strata are present in Iran, Afghanistan, central Asia, the Himalayan region, Thailand, Vietnam, China, Australia, New Zealand and Antarctica (Vaughan \& Pankhurst 2008).

Iran. There is little doubt that Cambrian trilobite faunas presently documented from Iran (IR) have distinct Gondwanan signatures, but the country comprises several tectonostratigraphic terranes and their position in relation to mainland Gondwana is not yet certain. The only exception is the Zagros Mountains, which nowadays constitute a margin of the Arabian Platform (AR); therefore, its location within the Gondwanan Cambrian margin is almost certain (Cocks \& Torsvik 2002). The position of central Iran in relation to Gondwana was more obscure during the early Palaeozoic, but general characters of the Ordovician faunas suggest that it was also located along the Gondwanan margin (Ghobadi Pour et al. 2006; Ghobadi Pour \& Popov 2009a) and became a separate plate tectonic entity no earlier than the Silurian (Hairapetian et al. 2008). As for the Alborz block, there is growing evidence that, during the early Palaeozoic, it was located in a relative proximity of South China (Ghobadi Pour 2006; Ghobadi Pour et al. 2007) occupying an intermediate position between East and West Gondwana (Lefebvre et al. 2005; Popov et al. 2009a, b). Cambrian trilobite faunas from various parts of Iran were mostly documented 30 or more years ago (King 1937; Wolfart 1974a, $b$; Fortey \& Rushton 1976; Kushan 1978; Wittke 1984) and only Peng et al. (1999) offered an adequate modern representation of the Epoch 3-Furongian trilobite faunas of the Alborz terrane. The weak point of these studies is the inadequate information on agnostoids. As a result, the correlation of local biostratigraphic units with global Cambrian stages is poorly constrained and the 
position of the Furongian base has not yet been defined with necessary precision. In Alborz, it can be placed tentatively somewhere near the top of the Palaeodotes-Torifera Zone (='Drepanura Zone' of Kushan 1978), which is correlated with the Kushanian of North China and the Mindyallan of Australia (Shergold \& Geyer 2003; for further discussion see Peng et al. 1999).

The generic affiliation of many taxa (e.g. Agnostus, Anomocare, Briscoia, Idahoia and Saukia) described by King (1937) from the Zagros Mountains requires revision and therefore they are not included in the supplementary data set. As one example of a form in need of re-evaluation, Saukia, which is illustrated by King (1937, plate 1, fig. 3), most probably belongs to Alborsella. Another problem is that a significant part of the collection studied by King (1937) came from xenoliths of Cambrian rocks in salt plugs and their stratigraphic position cannot be defined.

Afghanistan. Afghanistan (AF) has been poorly studied since the end of the 1970s and syntheses of the Cambrian (e.g. Wolfart \& Wittekindt 1980) generally portrayed Afghan geology within the context of the geosynclinal model. This has been improved in more recent syntheses, for example by Şengör (1984) and Boulin $(1988,1991)$. Tectonically, Afghanistan is located within the collision zone of Laurasia and Gondwana, and hence the tectonic history is dominated by events preceding and leading to the final Pliocene collision between the Indian Plate and the Afghan block (a collage of blocks assembled during the Cimmeride Orogeny, c. 210-180 Ma). For our purposes, the area is considered a lateral prolongation of the Iranian and Indian margins of East Gondwana. Cambrian trilobite-bearing strata are poorly known: nearly all of them are situated in the Panjao region (Wolfart, $1974 a, b$; Wolfart \& Kursten 1974), where trilobite-bearing limestones are latest Epoch 3 and Furongian in age. Those strata directly overlie dolostones presumed to be of Cambrian Epoch 3 .

Central Asia (Uzbekistan, Tajikistan and southern Kyrgyzstan). A significant part of central Asia, enclosed between the Kazakhstanian Orogen and the Tethyside units of northern Iran, is a rather obscure area, which has attracted little attention in recent analyses of the early Palaeozoic palaeo(bio)geography. It comprises several crustal blocks and Palaeozoic to Jurassic island arc fragments, which have been outlined most recently by Natal'in \& Şengör (2005) and Burtman (2006). Almost all published data on Cambrian trilobite faunas within this region (e.g. Hajrullina \& Yaskovich 1961; Hajrullina 1970, 1973; Yaskovich \& Repina 1975; Ghobadi Pour \& Popov 2009b) are confined to a single Palaeozoic tectonostratigraphic unit, which is known as the Alai terrane or microplate. It is separated from the Karatau-Naryn terrane and the Turan domain (as defined by Natal'in \& Şengör 2005) by late Carboniferous -early Permian sutures, and its early Palaeozoic margins were destroyed by collisions (Burtman 2006). The Alai terrane (AT) is commonly considered an extension of the Tarim microcontinent (Natal'in \& Şengör 2005; Burtman 2006), but the evidence for close associations of these two terranes in the early Palaeozoic is insufficient.

Cambrian to Early Ordovician fossils from the Alai terrane are relatively well known, but the faunas are preserved mostly in limestone olistoliths within Silurian slope-rise strata, suggesting the former existence of a neighbouring carbonate shelf (Ghobadi Pour \& Popov 2009b). Trilobite-bearing semi-autochthonous sediments of the Altykol and Rabut formations, extending from the upper part of Cambrian Series 2 to the Furongian, are locally preserved in the Turkestan Range (Hajrullina 1973). In these formations, the succession of the trilobite assemblages is rather evident, but the Furongian trilobites are rather poorly documented and their application for biogeographical analysis is limited. The Cambrian Series 3 trilobite fauna from the olistoliths is remarkably diverse and can be subdivided into four different associations (Repina et al., in Yaskovich \& Repina 1975), but precise correlation with the stages of the Series 3 is, however, rather uncertain and the trilobite associations are treated herein together in a single list.

Kazakhstanian island arcs and microplates. Following early platetectonic reconstructions (e.g. Scotese \& McKerrow 1990, 1991), Kazakhstan is still illustrated in some publications as a single plate located close to Siberia in the early Palaeozoic. However, it is now evident that Kazakhstania did not form an individual microplate until the late Silurian-Early Devonian (Windley et al. 2007; Popov et al. 2009a). Identification of early Palaeozoic tectonic units incorporated into the Kazakhstanian (KZ) or Altaid Orogen also remains a matter of debate (Şengör \& Natal'in 1996; Burtman 2006; Windley et al. 2007; Popov et al. 2009a). Three major tectonostratigraphic units can be recognized. In the southcentral Kazakhstan-northern Kyrgyzstan area, there are three major crustal terranes (Karatau-Naryn, North Tien Shan and Chu-Ili) amalgamated together sometime in Late OrdovicianSilurian times (Popov et al. 2009a). They are all probably of periGondwanan origin, but Cambrian trilobite faunas are well documented only for the Karatau-Naryn terrane (Ergaliev \& Pokrovskaya 1977; Lisogor 1977; Ergaliev 1980, 1983; Apollonov \& Chugaeva 1983; Ergaliev \& Ergaliev 2008; Ergaliev et al. 2008). There is also an extensive unpublished collection of Furongian trilobites assembled by the late M. K. Apollonov, which is currently under study. Data from that collection have been used in part to characterize the generic diversity of Furongian trilobites from the Karatau-Naryn terrane. According to the analysis of the early Palaeozoic geological history and faunal affinities by Popov et al. $(2009 a)$, the Karatau-Naryn terrane was probably united with South China sometime during the Terreneuvian-Cambrian Epoch 2 and rifted shortly before the beginning of Cambrian Epoch 3. By the Furongian and later, it occupied a marginal position in relation to other Kazakhstanian terranes. The biogeographical links of the Karatau-Naryn terrane with the South China Plate remained strong until the Late Ordovician.

In north-central Kazakhstan, there is another cluster of early Palaeozoic terranes representing one or more crustal microplates and fragments of volcanic arcs accreted to them during the Cambrian-Middle Ordovician (Dobretsov et al. 2006; Degtyarev \& Ryazantsev 2007). In some plate tectonic reconstructions, the crustal units are named the Kalmyk Kol-Kokchetav (Şengör \& Natal'in 1996) or the Shatsk and Kokchetav (Dobretsov et al. 2006) microplates. The documented early Palaeozoic geodynamic history of the region, including polarity and time of accretion of the surrounding Selety, Ishim and Stepnyak volcanic arcs, as well as the timing of island arc volcanism (Dobretsov et al. 2006), suggest that there was no close interaction between the northcentral and south-central clusters of Kazakhstanian terranes at least until the Late Ordovician, but the Middle to Late Ordovician faunas in both clusters bear distinct equatorial Gondwanan signatures (Fortey \& Cocks 2003; Popov et al. 2009a). The north-central Kazakhstanian crustal terranes are usually considered to be of Gondwanan origin. Şengör \& Natal'in (1996), however, placed them along the Siberian margin for the Ediacaran. The only source of information about the Cambrian trilobite faunas from that region are two publications by Ivshin (1962, 1979). These faunas derive from the Selety volcanic arc, which was accreted to the Kokchetav microplate margin sometime in the Middle Ordovician (Dobretsov et al. 2006).

There is strong evidence for oceanic separation between the central and eastern clusters of the Kazakhstanian terranes, suggesting that the source and the early Palaeozoic history of the terranes, situated east of the inferred oceanic suture, were different. With the exception of the Atasu-Zhamshy crustal terrane of Apollonov (2000), which is equivalent to the Atasu-Mointy unit of Şengor \& Natal'in (1996), this region represents a collage of several lower Palaeozoic island arcs of uncertain origin, developed either on oceanic crust or on a heterogenous basement (Windley 
et al. 2007; Popov et al. 2009a). Some of them have been originally intra-oceanic domains, whereas others may represent a detached active eastern Cambrian margin of Baltica, or were derived from other sources. The presently known Cambrian trilobite faunas documented by Ivshin $(1953,1956,1957,1962)$ and Lisogor (2004) most probably derived from at least three island arc domains named, in the data set, the Boshchekul, Agyrek and Chingiz regions. Trilobite faunas from Cambrian Epochs 2 and 3 in Agyrek are derived from limestone olistoliths embedded in Ordovician slope deposits (Koneva 1979). The original source of these rocks is not present in the surrounding area. The Furongian trilobite fauna of the Boshchekul terrane is only partly represented in the analysis and the late Furongian trilobites still require formal description.

Indian craton and Himalayan margin. The Proterozoic mosaic of peninsular India (IN) comprises a collage of crustal blocks dissected by Neoproterozoic-Cambrian crust-scale shear/suture zones. Among these, the Palghat-Cauvery suture zone has been identified as a trace of a Cambrian suture representing the Mozambique Ocean closure. According to the model of Santosh et al. (2009), an early rifting stage gave birth to the Mozambique Ocean, followed by the initiation of southward subduction of the oceanic plate beneath a thick tectosphere bearing the Archaean Dhawar craton.

An extensive Neoproterozoic-Cambrian succession developed in the area that now forms the Himalaya (HI). This was the seaward margin of India that deepened northwards during that time interval (present-day orientation; Jiang et al. 2003), although ichnofossil-bearing Cambrian deposits are recorded on the Indian craton in Rajasthan (Kumar \& Pandey 2008). Despite claims that the northern parts of the Himalaya represented a separate terrane during the Cambrian (DeCelles et al. 2000), combined faunal and detrital zircon analysis (Myrow et al. 2003, 2009, 2010) and palaeomagnetic data (Torsvik et al. 2009) suggest a continuous margin between the Indian and northern Himalayan regions during the Cambrian. Cambrian deposits dated by trilobites and other shelly fauna are known from the Himalaya of Pakistan and India (Jell \& Hughes 1997; Peng et al. 2009), and also from Bhutan (Hughes et al. 2011). Cambrian rocks occur extensively in the more proximal Lesser Himalaya (Hughes et al. 2005) and in the Salt Range of Pakistan, and also in the more basinward deposits of the Tethyan Himalaya, particularly in Kashmir and in the Zanskar-Spiti region of Himachal Pradesh (Hughes \& Jell 1999; Peng et al. 2009). The Lesser Himalaya has a well-dated Ediacaran-Cambrian boundary section that extends at least to the uppermost part of Cambrian Series 2, and probably into Series 3 . The Tethyan Himalaya in the Spiti-Zanskar region has Cambrian Series 3 rocks, as dated using trilobites (Jell \& Hughes 1997; Peng et al. 2009). The Bhutanese sections include the only Furongian trilobites known from the Himalaya (Hughes et al. 2011).

South China (or Yangtze block), North China (or Sino-Korean block) and Tarim. China and its northeastern prolongation into Korea consists of three large Proterozoic continental cratons, the Tarim (TA), North China (NC) and South China (SC) blocks, which are separated by Palaeozoic and Mesozoic accretionary belts, as well as several smaller blocks and terranes. In a recent palaeogeographical revision Zhou \& Zhen (2008) distinguished numerous Cambrian Chinese units, corresponding to different allochthonous continental masses (plates and terranes), and divided them largely on the basis of evidence from regional tectonics, palaeogeography and stratigraphy (Fig. 19.2). These areas are, from present-day northwest to southeast: $(1-2)$ the northern Xinjiang and Hinggan regions, considered as the mobile zones between the Siberia/Tarim and the Siberia/North China plates; (3) the middle Tianshan-Beishan region, considered as a part of Kazakhstania; (4) the Tarim plate; (5) North China; (6) the KunlunQinling region, a polycyclic orogenic belt composed of several intervening terranes; (7) the northern Qiangtang-Simao region considered as the northern extension of the Indochina or

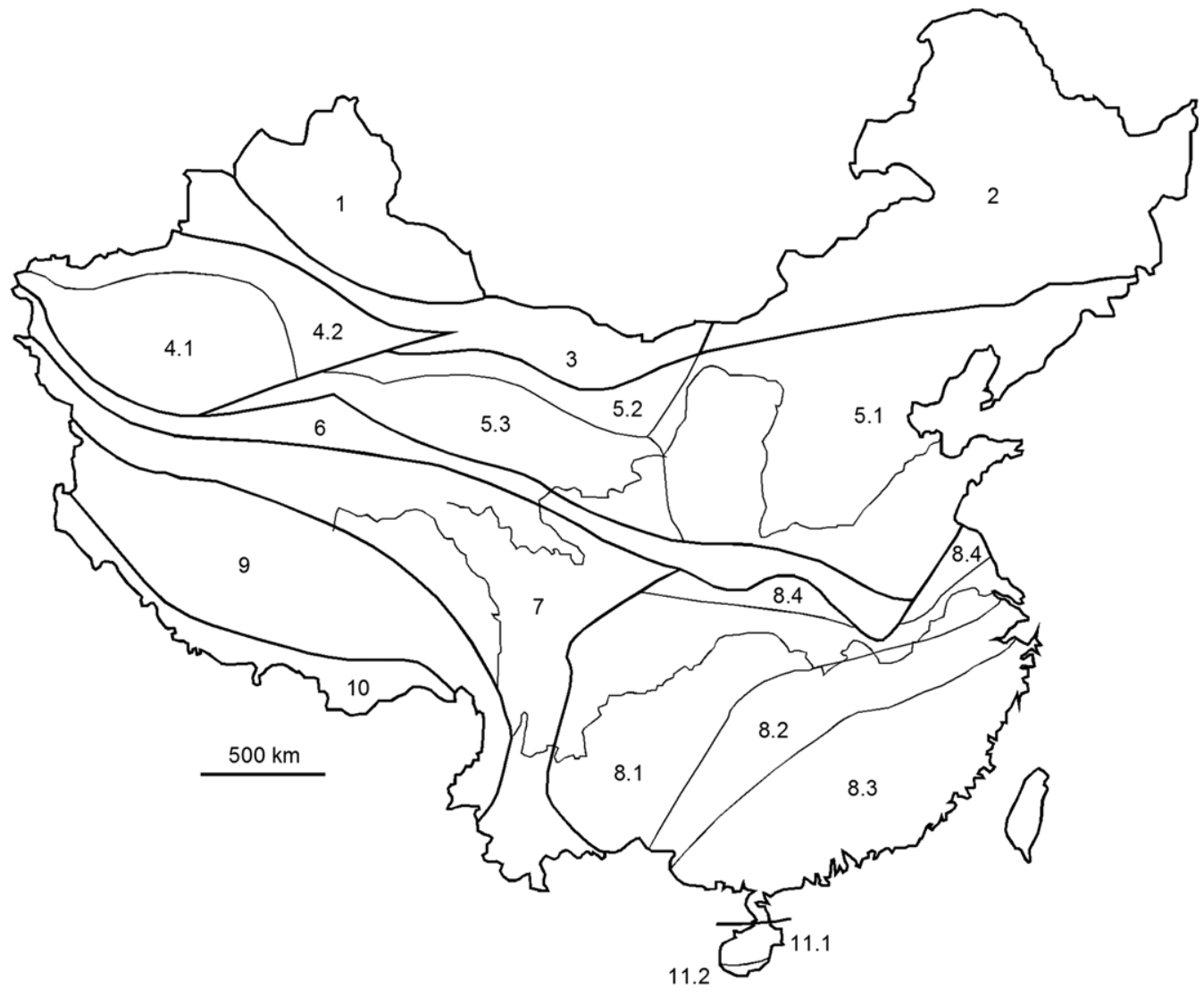

Fig. 19.2. Cambrian tectonostratigraphic units of China: 1, Northern Xinjiang region; 2, Hinggan region; 3, middle TianshanBeishan region; 4, Tarim plate: 4.1, BachuKalpin area, 4.2, Southern Tianshan area; 5, North China region: 5.1, Yellow River area, 5.2, Dunhuang-Alexa area, 5.3, QaidamQilian area; 6, Kunlun-Qinling region; 7, Northern Qiangtang-Simao region; 8, South China region: 8.1, Yangtze area, 8.2, Jiangnan area, 8.3, Cathaysia area, 8.4, Jiangbei area; 9, Baoshan-northern Tibet region; 10, southern Tibet region; 11, Hainan region: 11.1,Wuzhishan area, 11.2, Sanya area; after Zhou \& Zhen (2008). 
Annamia terrane (ANN); (8) South China; (9) the Baoshan-northern Tibet region, reported as a northern extension of the Sibumasu terrane; (10) the southern Tibet region, a prolongation of the Indian Plate; and (11) the Hainan region.

Several studies favour the hypothesis that these continental blocks and terranes were derived from Gondwana (Wang et al. 1999). A close biogeographical association of (i) Tarim and South China and (ii) Australia-India has been recognized for the Cambrian, suggesting that both assemblages may have been part of Gondwana in early Palaeozoic times (Metcalfe 1996; Jell \& Hughes 1997; Peng et al. 2009). However, it is less clear whether North China belonged to Gondwana or not during the same time span, owing to the biogeographical relationships of Cambrian Epoch 2 fossil faunas, which show links with Siberia and Laurentia (Burrett et al. 1990), although new evidence suggests a strong and specific link between the eastern Himalaya of Bhutan and North China during the Furongian (Hughes et al. 2011). In any case, palaeomagnetic data suggest that, during the Terreneuvian-Cambrian Epoch 2, North China, South China and Tarim were located adjacent to East Gondwana in low latitudes of the Southern Hemisphere (Huang et al. 2000).

The Sino-Korean block is bounded on the north by the central Asian fold belt. Its boundary with the southern Yangtze block is situated along the Qinling-Dabie-Sulu belt (Zhao et al. 1996; Li \& Powell 2001). The Yangtze block consists of four major tectonostratigraphic units that reflect a proximal-distal palaeogeographical trend: (1) the Yangtze Platform; (2-3) the Jiangnan (southern) and Jiangbei (northern) shelf slopes; and (4) the Cathaysia/Pearl River deep basin (Zhou et al. 2008). In China, the SinoKorean block can be subdivided into three major tectonostratigraphic areas: (1) the Yellow River (or North China Platform); (2) the Dunhuang-Alexa area; and (3) the Qaidam-Qilian (comprising two terranes) area. The block's northeastern prolongation into the Korean Peninsula has been a matter of debate. Chough et al. (2000) considered the difference in faunal composition of the Taebaek (bearing endemic trilobites of the Sino-Korean block) and Yeongwol (bearing cosmopolitan and pelagic trilobite) groups in Korea to be a consequence of their difference in depositional environments, the Taebaek representing inner-shelf and the latter offshore, deeper-water environments. Recent geotectonic considerations involving the Korean Peninsula (Cluzel et al. 1990, 1991; Yin \& Nie 1993) suggested that the peninsula was divided into three major parts in the early Palaeozoic, namely, the Nangnim, the Yeongnam and the Gyeonggi massifs. The Nangnim and Yeongnam areas were considered to occupy the marginal part of the Sino-Korean block, whereas the Gyeonggi area was connected to the Yangtze block. Their boundary or suture has been drawn along the Imjingang Belt (Cluzel et al. 1991; Yin \& Nie 1993; Ree et al. 1996). Cluzel et al. (1991) interpreted the eastern half of the Taebaeksan Basin (Duwibong unit of Cluzel et al. 1990; Taebaek Group) as a carbonate shelf fringing the Sino-Korean block, whereas the western half of the basin (Yeongwol unit of Cluzel et al. 1990; Yeongwol Group) was part of the Yangtze block. By contrast, Chough et al. (2000) and Choi et al. (2001), based on the palaeobiogeographical features derived from the Cambrian-Ordovician trilobites of the basin, suggested that the entire Taebaeksan Basin belonged to the SinoKorean block and was a shallow marine, carbonate-siliciclastic basin with progressively deeper water to the west (Yeongwol area), a proposal that is followed here. As a result, the Cambrian trilobite faunal contrast between the Taebaek and Yeongwol groups can be attributed to differences in depositional settings (Choi \& Kim 2006).

Tarim is a rhomboidally shaped basin, and Cambrian strata are today distributed mainly along the northern periphery. As a result of the breakup of Rodinia (560-550 Ma; Veevers et al. 1997), Tarim drifted from the Kimberley craton in Australia ( $\mathrm{Li} \&$ Powell 2001; Chen et al. 2004). There is no clear early Palaeozoic suture zone discovered to the south of the Tarim block that separates it from the Sino-Korean block (Zhou \& Zhen 2008). Some authors once considered both domains to have formed a rigid block since the Neoproterozoic because the two blocks are connected by an almost continuous Neoproterozoic-Palaeozoic sedimentary succession. However, this idea has been abandoned because available palaeomagnetic data suggest that they did not assemble their present configuration until sometime in the Mesozoic.

Although traditionally the Cambrian trilobites have been biogeographically analysed according to only three units, named North China, South China and Tarim (southern Xinjiang), we follow recent palaeogeographical distinctions (Zhou \& Zhen 2008; Zhou et al. 2008), in which shallow- and deeper-water facies are distinguished.

Australia-New Zealand-Antarctica. Shallow intracratonic basins developed across a large area of the central Australian craton (AU) during the Neoproterozoic and early Palaeozoic (a halfbillion-year sedimentary record). From west to east, these are the Bonaparte, Ord, Daly, Wiso, McArthur, Georgina, Ngalia, Amadeus, Officer, Warburton, Arrowie and Stansbury basins, and the Adelaide foldbelt (Brock et al. 2000). In Tasmania, Victoria and western New South Wales, Neoproterozoic and Terreneuvian-Series 2 sedimentary rocks were deposited along a passive margin (Foden et al. 2006). On the (present) eastern margin of the Australian craton, the entire subsurface Warburton Basin comprises a mixture of Terreneuvian-Series 2 volcanic rocks and Series 3 and Furongian shelf and outer shelf sediments (Sun 1996). Series 3 and Furongian clastic sedimentary rocks and associated volcanic rocks were deposited in the more tectonically active areas of Tasmania, Victoria, and New Zealand that were associated with the Ross-Delamerian Orogeny.

Supercontinent breakup in NW Australia during the Neoproterozoic-Cambrian transition, resulting in the Tarim block separating from the Kimberley area, gave rise to the Antrim plateau basalts and the Bonaparte Basin. As suggested by the poleward drifting of West Gondwana, palaeomagnetic results from Australia also suggest that Gondwana rotated anti-clockwise around an axis near northern Victoria Land, Antarctica, during the Cambrian, but rotation stopped at the end of the Cambrian. This change in sense of plate rotation coincides with the termination of the Ross-Delamerian Orogeny along the Transantarctic Mountains and southeastern Australia, which started during the Terreneuvian (or possibly the latest Neoproterozoic) in the Transantarctic Mountains, and in Cambrian Epoch 2 in South Australia. In Tasmania and northern Victoria Land, obduction of an intra-oceanic island arc during Epoch 3 and the oldest intrusion of granitoids in the Kanmantoo flysch wedge (c. $516 \mathrm{Ma}$ ) are all related to the Ross-Delamerian Orogeny (Münker \& Crawford 2000; Li \& Powell 2001; Jago et al. 2003; Foden et al. 2006). Westward subduction of the Palaeo-Pacific Ocean along the eastern margin of Australia-Antarctica commenced during the Terreneuvian in northern Victoria Land and in Epoch 3 in South Australia and continued near the end of the Cambrian at about $490 \mathrm{Ma}$. Cambrian Series 3 and Furongian rocks of the Takaka terrane of the South Island of New Zealand were part of a volcanosedimentary arc complex (Münker \& Cooper 1999).

\section{Does trilobite-based biogeographical information support terrane distinctions?}

Traditionally, the distinction between continental margins, blocks, terranes and basins has been mainly based on biogeographical differences. Three subdivisions were usually recognized in biogeographical comparisons: realm, region and province. The realm was distinguished by the presence or absence of endemic orders, superfamilies or families; the region by families, subfamilies and 
genera; and the province by characteristic associations of genera and species (e.g. Jell 1974; Kobayashi 1976; Theokritoff 1979; Lu 1981; Zhang 1989, 2006; Chang 1998). During the last decade, cladistic analysis applied to phylogenetic biogeography has provided an alternative way to assess faunal relationships.

From the earliest occurrence of trilobite faunas in Cambrian Series 2 there is clear evidence of biogeographical differentiation into two main provinces: the Olenellid Province, comprising much of Baltica, Laurentia and Siberia, and the Redlichiid Province of Gondwana (Kobayashi 1971, 1972). The overlap of both provinces in some peri-Gondwanan margins led Pillola (1991) to erect the intermediate Bigotinid Province. Subsequent modifications of this three-fold biogeographical subdivision of Epoch 2 have increased the nomenclature of biogeographical units, which is summarized in Figure 19.3.

For Epoch 3 and the Furongian Epoch, Palmer (1972) reported a more complicated scheme involving four provinces for continental seas, and three others for exposed shorelines. Terms such as Pacific, Atlantic or Acado-Baltic were proposed to distinguish some distinct biogeographical features. The Acado-Baltic biogeographical unit (initially described by Sdzuy 1972, although subsequently modified by other authors), also known as Paradoxidian or Paradoxides Realm or Province, is one of the more robust Epoch 3 biogeographical provinces; it is based on the presence of the paradoxidid-solenopleurid-conocoryphid assemblage, which is spread throughout Avalonia, the Mediterranean and central-European areas, and Baltica (Álvaro \& Vizcaïno 2003). Babcock $(1994 a, b)$ pointed out that this assemblage of trilobites was widely distributed in cool marine waters of various latitudes, including deep-water settings surrounding tropical Laurentia.

The application of biogeographical concepts for the discrimination of Cambrian terranes or microcontinents has highlighted new unresolved problems, which are still under debate. In this paper, several terranes have received special attention: Avalonia, Cuyania, Ossa-Morena, the Chinese domains, the Alai terrain and the Kazakhstanian island arcs and microplates. Although some authors have followed Havlíček et al.'s (1994) concept of Perunica, which included the German and Barrandian (an area situated in the central part of the Bohemian Massif) deposits, Cambrian faunas from Perunica are not differentiable from those of other Mediterranean areas. As a result, we consider SaxoThuringia and Bohemia as a part of West Gondwana during the Cambrian. In addition, Babcock's $(1994 a, b)$ works on a paradoxidid-solenopleurid-conocoryphid assemblage from native Laurentian strata in North Greenland suggests that the finding of an assemblage of this type in association with a markedly different endemic tropical shelf fauna is not certain evidence of an exotic terrane. Structural/tectonic and stratigraphic evidence must be used to supplement biogeographical information to arrive at a conclusion as to a terrane's provenance.

\section{Avalonia}

The Gondwanan affinity of the so-called maritime or Acadian terranes in North America and Britain is evident from faunal data (Samson et al. 1990; Álvaro et al. 2003a; Cocks \& Fortey 2009). These authors called attention to a possible cool-water influence on these Avalonian faunas related to their deep and basinal position, and not necessarily to palaeolatitudinal settings. However, Landing (1996, 2005) and Geyer \& Landing (2001) pointed out that important differences existed during the Cambrian between the Avalonian terranes, which record a 'cool, high-latitude fauna', and the western Mediterranean area, which records an evolution of subtropical to temperate fauna.

Landing (1996) argued that no lithological, biotic or geological evidence supports a conclusion that Avalon was contiguous to West Gondwana in the Neoproterozoic and Cambrian. Three arguments were posed by Landing (2005), leading to the conclusion that Avalon was an independent palaeocontinental block: (1) lithostratigraphic distinctiveness of a persistently cool-water, higher-latitude Avalonian microcontinent with successions dominated by marine siliciclastics, as compared with coeval carbonatedominated, low-latitude successions in Morocco; (2) a Cambrian Series 2 biotic distinctiveness of the archaeocyathan-free Avalonia, which shares few faunal elements with the archaeocyathanbearing strata of Morocco and Spain; and (3) geological evidence of early Palaeozoic separation. However, several workers have offered arguments supporting the traditional Cambrian Avalonian-Gondwanan link. Pouclet et al. (2007) criticized Landing's lithostratigraphic correlation with the shallower parts of the Moroccan margin, which largely ignored the deeper grabens exposed in the westernmost side of the High Atlas and the Coastal Meseta, where scattered areas of carbonate productivity were associated with uplifted horst shoulders (Álvaro et al. 2008). The absence of archaeocyathan-bearing carbonates is seemingly related to the southern (temperate) boundary of their colonization potential, as these reefs were dominantly within $30^{\circ}$ of the equator (Courjault-Radé et al. 1992; McKerrow et al. 1992), and absent southwards, as in South America. McKerrow et al. (1992) argued that the record of microbial and skeletal biomicrite deposits, with fenestral fabrics and acicular carbonate cements, do not suggest a high palaeolatitudinal position for Avalonia. In addition, Álvaro et al. (2003a) reported 17 trilobite genera in common

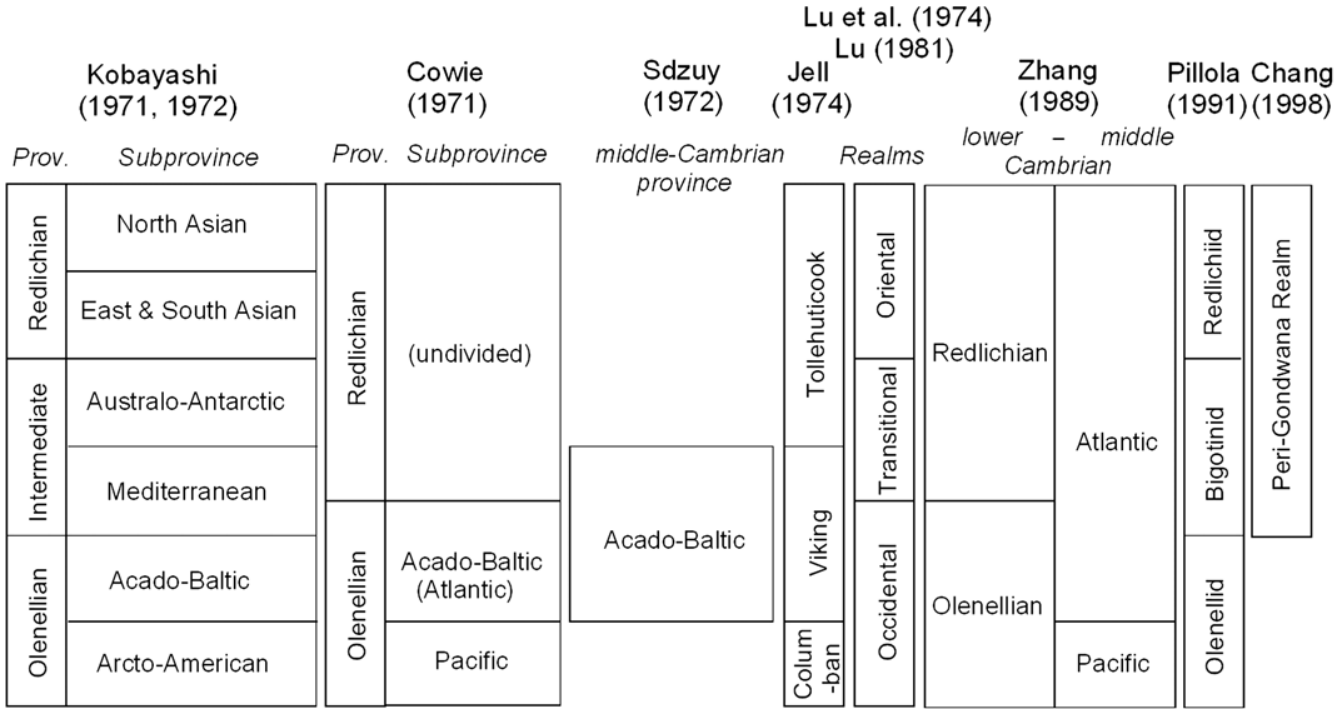

Fig. 19.3. Major Cambrian palaeobiogeographical units erected until the end of the twentieth century; based on Kobayashi (1971, 1972), Cowie (1971), Sdzuy (1972), Jell (1974), Lu et al. (1974), Lu (1981), Zhang (1989), Pillola (1991), and Chang (1998). 
between Cambrian Series 2 of Avalonia and the western Mediterranean region. Some Epoch 3 Avalonian benthic communities belong to the so-called conocoryphid biofacies (Álvaro \& Vizcaïno 2003), a natural assemblage of trilobites with many blind forms living alongside larger-eyed contemporaries, which can be recognized as a part of the Menevian faunas (Cocks \& Fortey 2009). Pouclet et al. (2007) also described a similar late Ediacaran-Terreneuvian geodynamic evolution in Avalonia and Morocco, characterized by the development of extensional tectonics leading to the record of grabens containing the same continental tholeiites as in the Atlas.

Although Avalonia was an independent terrane throughout the Ordovician, merging with Baltica at about the OrdovicianSilurian transition time (443 Ma), the varied basement terranes underlying Avalonia were aggregated to the margin of Gondwana before $650 \mathrm{Ma}$. Some substantial transform movements occurred along the Gondwanan margin between 610 and $530 \mathrm{Ma}$, but the Avalonian area remained adjacent to Gondwana until about the end of the Cambrian (490 Ma), when the rift-drift initiation of the opening Rheic Ocean between Gondwana and Avalonia began (Fletcher \& Rushton 2007; Cocks \& Fortey 2009).

\section{Cuyania}

The Laurentian affinity of Cuyania is supported by a variety of lines of evidence including faunal biogeography, an EarlyMiddle Ordovician magmatic arc development on the marginal continental crust of Gondwana (the Famatinian Arc), and the onset of Middle Ordovician metamorphism (equated with the collision stage of the arc). However, some authors have proposed an alternative origin for the terrane in another part of Gondwana, with Ordovician emplacement by massive strike-slip movement along the margin, based on the presence of Mesoproterozoic basement rocks in Cuyania supported by zircon analysis. The record of Cambrian-Middle Ordovician carbonate productivity in Cuyania has often been cited as evidence of a Laurentian affinity. For some authors, as discussed in the Avalonian case, the lack of carbonate production can be associated with other processes (such as terrigenous input and bathymetry), and the biogeographical affinity of Cuyania might also be explained as a result of similar palaeolatitudes rather than a close palaeogeographical connection to Laurentia (Ramos 2004; Finney 2007; Vaughan \& Pankhurst 2008).

\section{Ossa-Morena}

The southern boundary of Ossa-Morena in the Iberian Peninsula is usually considered as a suture because of the presence of Variscan ophiolites. However, the interpretation of its northern boundary (the Badajoz-Córdoba shear zone) is still a matter of discussion owing to the superposition of a Variscan ductile shear zone with a contrasting metamorphic signature. Some authors interpret this lineament as the suture of a terrane corresponding to oceanic domains developed in connection with the early Palaeozoic rifting event recorded inside Ossa-Morena (Simancas et al. 2009), whereas others (e.g. Abalos et al. 1991; Azor et al. 1994; Ribeiro et al. 2007) consider its northern boundary as a simple Variscan structure. In any case, the northern boundary of OssaMorena could not represent a wide Cambrian oceanic domain, in view of close trilobite similarities with Morocco and Iberia. In addition, Álvaro et al. (2003a) reported a coeval occurrence of archaeocyathan-microbial reefs in Morocco, Ossa-Morena and Cadomia (the Armorican Massif) preceding the subsequent spread of these features into the rest of the western Mediterranean region. They also showed a preferential biogeographical link with Avalonia and Morocco during Cambrian Epoch 2, a link that disappeared during the following epoch.

\section{Chinese domains}

With the exception of northern Xinjiang and Tibet, Cambrian trilobites are well recorded throughout the Chinese tectonostratigraphic units. China was first considered to be assignable to a single biogeographical realm in the Cambrian, called the Oriental Realm by Lu et al. (1974) and the Perigondwanan Realm by Palmer \& Repina (1993) and Zhang (2003). This realm was erected on the basis of several endemic clades, such as the superfamilies Redlichioidea and Dameselloidea, which flourished in China. The distribution of most of their included genera was largely restricted to SE, central and south Asia, the Middle East, Australia and Antarctica. A similar view was presented by Yang (1988), who suggested the existence of another biogeographical unit, called the Hinggan-Mongolia Province, located to the north of the realm (then named the Asian-Australian Realm). Recent work has shown evidence that both North and South China shared strong faunal similarities with the Himalayan margin.

A recent synthesis of Cambrian tectonostratigraphic units in China (Zhou \& Zhen 2008) has differentiated new terranes and allochthonous units with East Gondwanan affinity, identifying clear suture contacts and trilobite-based biogeographical properties. The authors have established four Chinese terranes: the middle Tianshan-Beishan, Hainan, northern Qiangtang-Simao and Baoshan-northern Tibet domains (the latter is discussed by some authors because Baoshan is linked to the Lhasa block, which is south of the Qiangtang block). The middle TianshanBesihan terrane was referred to the Tarim Province by Yang (1988), although the occurrences of Cambrian Epoch 2 trilobites such as Calodiscus, Edelsteinaspis, Pagetides, Poliellina, Serrodiscus and Tannudiscus suggest a faunal link with Sayan-Altay and Tuva of Russia. Affinities with Kazakhstan, Siberia and Laurentia rather than Tarim (Zhou et al. 1996) are also indicated. During Epoch 2, this Chinese terrane, or even possibly the entire Kazakhstan region, might have been located not far from Siberia. By contrast, the lower part of Cambrian Series 3 is characterized by the occurrence of trilobites (such as Galahetes and Xystridura) that indicate close affinities with Australia and Antarctica (Brock et al. 2000). The Cambrian Epoch 3-Furongian transition has yielded shallow-water trilobite faunas (Lin et al. 1996) that include shared forms with North and South China, such as Amphoton (also found in Australia) and Crepicephalina. The Australian connection continued during the Furongian, as illustrated by the presence of Atopasaphus, Golasaphus and Lorretina (Lu et al. 1986). The Hainan terrane has yielded an impoverished trilobite fauna, including Galahetes and Xystridura, sharing the biogeographical affinities described for the middle Tianshan-Beishan terrane. The northern Qiangtang-Simao terrane has also yielded a few Cambrian taxa, such as the genera Calvinella, Haniwa, Kunmingaspis and Mictosaukia (Zhou 1982; Hughes et al. 2002), reflecting biogeographical links with Australia, North and South China, and Tarim. The 'Baoshan-northern Tibet' domain, a palaeogeographical concept that needs revision, has yielded 38 Furongian trilobite genera and subgenera of trilobites, 30 of which are shared with those of the slope belt of South China suggesting a shallow, outer shelf setting.

\section{Alai terrane}

Most of the publications focused on Cambrian Series 2-3 trilobite faunas of the Alai terrane (AT), Turkestan, were completed more than four decades ago by researchers familiar with Siberian trilobite faunas, but without sufficient knowledge of Cambrian faunas presently documented from China. Not surprisingly the generic affiliations of a number of taxa (e.g. Kooteniella, Gaphuraspis, Jangudaspis, Metanomocarella, Pseudanomocarina and 
Shoriella) have a strong 'Siberian accent' and require considerable revision. At the same time, up to 18 Cambrian Epoch 3 genera are endemic to the Alai terrane. Gondwanan signatures of the Alai terrane are mixed. Genera such as Amphoton, Corynexochina, Dorypyge, Glyphasphellus, Lisania and Pianaspis are also known from South China and occur in some Kazakhstanian terranes. Jincella, Parasolenopleura, Ptychoparia and Skreiaspis are characteristic of mid-latitude West Gondwanan faunas and partly Baltica, but they are not documented from South China or Tarim. In addition, the chengkouiid Acanthomicmacca (= Jaskovitchella) is also known from the Cambrian of Avalonia, which was an integral part of the North African sector of Gondwana in the Cambrian. The Gondwanan affinity of the Cambrian faunas of the Alai terrane is also evinced by rhynchonelliform brachiopods, including the occurrence of Chile and the protorthide Glyptoria, which are otherwise known from Series 3 of the Rift Valley (Bassett et al. 2002; Ghobadi Pour \& Popov 2009b). It is most probable that, during the Cambrian, the Alai terrane displayed peri-Gondwanan affinities and occupied intermediate positions between 'West' and 'East' Gondwana. Abundance of local endemic genera may also suggest its separation from mainland Gondwana and it probably did not constitute a single entity with the Tarim microcontinent.

\section{Kazakhstanian island arcs and microplates: Karatau-Naryn, Selety terrane and eastern Kazakhstanian terranes}

Close affinities of the Cambrian Epoch 2 trilobite fauna from Karatau-Naryn to those of South China are well established. In particular, the trilobite assemblages of Malyi Karatau described by Ergaliev \& Pokrovskaya (1977) belong to the typical Redlichia fauna, which is characteristic also of South China and the Australian sector of Gondwana (Pillola 1993). The list of common taxa, sometimes down to species level, includes Redlichia chinensis, which is widespread in South China (Zhang et al. 1980) and Hebediscus orientalis, known also from the Shipai Formation (Series 2) of western Hupei, South China. Ushbaspis (=Metaredlichioides Chien \& Yao, in Lu et al. 1974) is also well represented in South China. In addition, the low-diversity fauna of linguliformean brachiopods includes species that also occur in South China (Holmer et al. 2001). The presence of trilobites of the family Lisaniidae in the faunas of the Karatau-Naryn terrane during Epoch 3 also implies a strong link to the faunas of South China. The Furongian trilobite fauna from the Kokbulak and Kamal formations of Bolshoi Karatau (Ergaliev 1983) shows a distinct similarity to the marginal faunas characteristic of outer shelf biofacies in South China, whereas Amzasskiella, Charchaqia, Lophosaukia and Promacropyge are also represented in the Furongian trilobite fauna described by Troedsson (1937) from eastern Tien Shan and South China (Lu \& Lin 1989; Peng 1990, 1992). Trilobite associations from the Hedinaspis sulcata and Lophosaukia beds (upper Furongian) of Malyi Karatau, partly characterized by Apollonov \& Chugaeva (1983) and Apollonov et al. (1984), also show strong affinities to the contemporaneous trilobite faunas of South China, including the co-occurrence of Acrocephalaspina, Ivshinagnostus, Karataspis, Probilacunaspis and Taoyuania (=Batyraspis; Ergaliev 1980; Peng 1992).

The Cambrian Epoch 2 trilobite association from Selety is of low diversity and, among five listed genera, only Erbiella shares a Siberian signature, whereas Glaphuraspis is endemic. Most important, however, is that the 'Atdabanian' bradoriid assemblage of Selety (which contains Alutella, Indota, Tsunyiella and possible cambriids; Williams et al. 2007) shows a distinct resemblance to the bradoriid faunas from South China and Australia, suggesting a subequatorial, peri-Gondwanan position of that terrane at least during Cambrian Epoch 2. The Furongian trilobite fauna of Selety includes a significant portion of endemic genera, which is consistent with a possible intra-oceanic location of the island arc during that time. However, most of the taxa described by Ivshin (1962) are based on isolated cranidia and this fauna requires considerable revision.

The Cambrian Epoch 2 trilobite fauna of Chingiz comprises just three genera, two of them (Labradorina and Bajanaspis) Kazakhstanian endemics (Ivshin 1979). Among them, Bajanaspis is also present in the contemporaneous trilobite assemblage from Agyrek. Epoch 3 trilobite faunas from eastern Kazakhstanian terranes (Agyrek, Boshchekul, and Chingiz) show few similarities to each other, and the few genera in common (e.g. Hypagnostus, Kootenia, Kooteniella and Olenoides) are cosmopolitan. The affinity of these faunas is also uncertain, but the occurrence of Chondragraulos and Erbia in the Agyrek assemblage suggests a link with Siberia. The Furongian trilobite fauna is documented only for the Boshchekul terrane. It represents a mixture of cosmopolitan genera and local endemics; some of them (Karagandoides, Lunacephalus and Obrucheviaspis) have been also recorded from the Selety terrane. Most probably, the eastern Kazakhstanian terranes represent fragments of Cambrian intra-oceanic volcanic arcs. The occurrence of endemic genera shared with two or more terranes suggests some interactions between these faunas, which were variable in time, but their affinity with contemporaneous faunas inhabiting shelves of other Cambrian continents is uncertain.

\section{Trilobite biogeography and the timing of the Cambrian radiation}

Fortey et al. (1996) were the first to use palaeobiogeographical patterns of the Cambrian Epoch 2 trilobites to make inferences about the timing of the Cambrian radiation. There have been other analytical attempts at gauging the timing of this radiation, but these have primarily focused on extant taxa (e.g. Davidson et al. 1995; Wray et al. 1996; Ayala et al. 1998; Bromham et al. 1998). The trilobites are ideal candidates for inferring the timing of the Cambrian radiation owing to their abundance and diversity across numerous palaeogeographical regions, and worldwide occurrence of trilobite-related ichnofossils pre-dating the mineralization of their trace-makers (Lieberman 1999). Fortey et al. (1996) argued that biogeographical (and other) evidence indicated that the evolutionary history of trilobites extended well back into the Neoproterozoic. A cryptic (pre-Cambrian Epoch 2) evolutionary history has also been suggested for other Cambrian arthropods, such as arachnomorph arthropods (Hendricks \& Lieberman 2007) including nektaspids (Paterson et al. 2010). The earliest trilobites were already differentiated into two biogeographically distinct faunas, the Olenellid Province of Laurentia, Siberia and Baltica, and the Redlichiid Province of Gondwana. Fortey et al. (1996) argued that this biogeographical differentiation could best be explained by a vicariance event associated with the breakup of Rodinia, which occurred around $750 \mathrm{Ma}$; this date significantly pre-dates the first appearance of trilobites in the fossil record, which is approximately $521 \mathrm{Ma}$.

Fortey et al. (1996) provided another important step in the use of Cambrian Epoch 2 trilobite biogeography to study the nature and timing of the Cambrian radiation by defining biogeographical provinces largely corresponding to the distribution of the eponymous trilobite suborders Olenellina and Redlichiina. At the time, it was not possible for these authors to incorporate detailed phylogenetic information into their study. Subsequently, phylogenetic analysis by Lieberman (1998) revealed that not all of the Olenellina, as traditionally defined, were monophyletic, as some taxa assigned to the group were more closely related to taxa in the suborder Redlichiina. Thus the 'Olenellid' biogeographical province is paraphyletic. Lieberman (1997, 1998, 1999, 2001, $2002 a, b, 2003 a, b)$ and Meert \& Lieberman $(2004,2008)$ pursued additional phylogenetic and biogeographical studies of these trilobites, partly to consider the issue of trilobite origins and the 
timing of the Cambrian radiation in greater detail. The biogeographical method used in these studies is a modified version of Brooks Parsimony Analysis, which is described in detail in Lieberman \& Eldredge (1996) and Lieberman (2000). This method captures information about the evolution of clades across geographical space and how this evolution is associated with episodes of vicariance and geodispersal.

Biogeographical analysis employing phylogenies of a large sample of Cambrian Epoch 2 trilobites from all three biostratigraphical regions (Fallotaspis, Nevadella and Bonnia-Olenellus) and all major Cambrian cratons revealed a well-resolved vicariance tree and a poorly resolved geodispersal tree (Lieberman 2003a; Meert \& Lieberman 2004; Fig. 19.4). This provides evidence that vicariance played the dominant role in influencing early trilobite evolution, with episodes of geodispersal appearing more muted. This makes sense given the tectonic regime of this time, which was largely one of continental fragmentation. Furthermore, the vicariance tree reveals close biogeographical relationships between: (1) Siberia, marginal West Gondwana and present-day southwestern North America; (2) Baltica and what was formerly the eastern margin of Laurentia; and (3) parts of East Gondwana. The first region largely corresponds to the geometry of the Neoproterozoic supercontinent Pannotia, which began to fracture at 550$600 \mathrm{Ma}$ (Meert \& Lieberman 2004, 2008). Given the absence of dispersal, this phylogenetic biogeographical topology suggests that the origin of these trilobites may be constrained to have occurred before the breakup of Pannotia. This implies that the trilobite lineage extends back at least 10-60 myr before the start of the Cambrian, which corresponds to a time of 30-80 myr before the first appearance of trilobites in the fossil record. Moreover, the phylogenetic position of trilobites as derived metazoans and euarthropods suggests that a significant amount of cladogenesis in many metazoan groups must have transpired before the start of the Cambrian. This actually matches the results from palaeontological studies of other metazoan groups including cnidarians (e.g. Cartwright et al. 2007). Finally, Meert \& Lieberman (2004) were also able to predict that the biogeographical origins of trilobites may have been in modern-day Siberia, an origin shared by archaeocyaths (Debrenne 1991; Rowland \& Shapiro 2002).

\section{Biogeographical links during Cambrian Epoch 2}

Brock et al. (2000) summarized some of the biogeographical links indicated by Cambrian faunas of Australia, such as: (1) relatively strong ties between trilobites and other shelly faunas from East Gondwana and Laurentia throughout the Cambrian; (2) strong faunal ties with South China during the Cambrian Epoch 2 (see also Paterson \& Brock 2007), followed by a rapid decrease in shared taxa during the Epoch 3-Furongian; and (3) relative faunal affinities with North China during Epoch 2, which became stronger during Epoch 3 and the Furongian. This major shift in biogeographical connections between Australian and Chinese faunas suggests modification in oceanic circulation patterns or a major change in the relative positions of the Chinese crustal blocks with respect to East Gondwana during the Cambrian.

In West Gondwana, the earliest trilobites from the Anti-Atlas Mountains are among the oldest trilobites known so far on global scale (Geyer et al. 1995). These faunas include several fallotaspidids (Eofallotaspis) and bigotinids (Bigotinops and Hupetina), which were subsequently replaced by other fallotaspidids, redlichiids and bigotinids. Elsewhere, fallotaspidids s.l. occur in Laurentia and Siberia. Redlichiid-saukiandid trilobites (such as Marsaisia, Pararedlichia, and Resserops) suggest biogeographical links with South China, whereas some bigotinids are also known from Cadomia, Ossa-Morena and Siberia (Álvaro et al. 2003a). Fallotaspidids were subsequently replaced by neltneriids, whilst primordial ellipsocephaloids and eodiscoids (Delgadella, Hebediscus) appeared. Other ellipsocephalids (Berabichia, Issafeniella, and Sectigena) have their counterparts in the Cantabro-Iberian Basin, marginal Baltica (Holy Cross Mountains), Antarctica (formerly named Chorbusulina) and the Siberian genera Charaulaspis and Chorbusulina, the latter, accompanied by Hebediscus and Triangulaspis, are probably widespread. Acanthomicmacca, Calodiscus, Hebediscus, Serrodiscus and Triangulaspis (Geyer \& Palmer 1995) are known from Avalonia, marginal Baltica (Holy Cross Mountains) and the Siberian Platform. The end of the Cambrian Epoch 2 is characterized by new links between Avalonia and West Gondwana, including some eodiscoids and species of Protolenus, Strenuella and possibly Callavia. Another 12 genera known are from Avalonia and the Taconic Belt. The succession from the Holy Cross Mountains in Poland (marginal part of Baltica) also shares a number of ellipsocephalid genera with the West Gondwanan (Iberia, Morocco) and Avalonian faunas (Żylińska \& Szczepanik 2009; Żylińska 2013). Available information on trilobites of central Iran and Zagros is far from perfect and cannot be applied for detailed biogeographical analysis; however, the Cambrian Epoch 2 trilobites described by King (1930) and Wolfart (1974a, b) from southern Iran (central Iran and Zagros) include Redlichia, and can be broadly considered as Gondwanan (Pillola 1993).

The trilobite assemblages of the Siberian Platform are dominated by eodiscoids (Calodiscus, Delgadella, Hebediscus, and Neopagetina), ellipsocephalids (Bergeroniellus, Lermontovia, Paramicmacca and Triangulaspis), and fallotaspidoids (Judomia), pointing to biogeographical communications with the Far East, the Altai-Sayan foldbelt, Mongolia, Kazakhstan, China, Avalonia, Baltica and West Gondwana (Morocco, Taconic Belt, Ossa-Morena, and Germany). A relatively narrow belt-like zone separates the inner shelf from the open basin, the former being characterized by the abundance of microbial and archaeocyathanmicrobial reefs and fringing grainstone shoals (Savitsky \& Astashkin 1979; Astashkin et al. 1984; Rozanov \& Sokolov
VICARIANCE

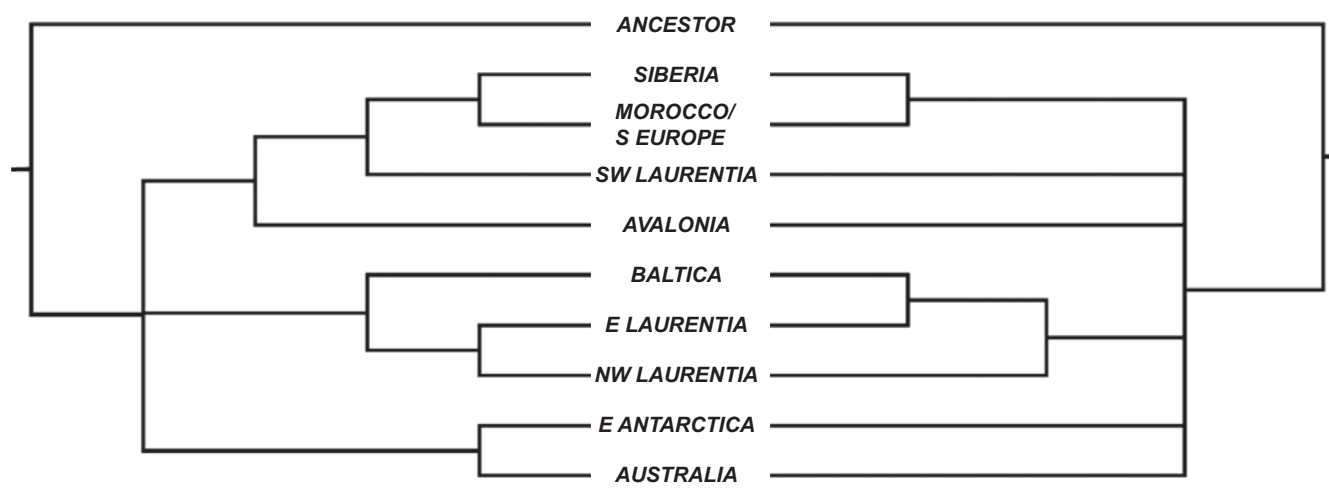

Fig. 19.4. Vicariance and geo-dispersal analysis for the beginning of Cambrian Epoch 2; from Lieberman (2003a) and Meert \& Lieberman (2004). 
1984). The reef and reef slope areas displayed highly diverse although rather endemic trilobite assemblages, composed of fallotaspidoids, ellipsocephaloids and eodiscoids. The characteristic occurrence of Delgadella, Hebediscus, Nevadia and Triangulaspis in this palaeogeographical sector indicates biogeographical connections with Mongolia, the Altai-Sayan foldbelt, Kazakhstan, Avalonia and Gondwana (Taconic Belt, Ossa-Morena and Morocco). The trilobite assemblages of the upper part of Cambrian Series 2 are dominated by endemic genera of aldonaiids, calodiscids, corynexochids, dinesids, dolichometopids, dorypygids, edelsteinaspidids, granularaspidids, hebediscids, jakutids, judomiids, namanoiids and ptychopariids. Representatives of the superfamily Ellipsocephaloidea were characteristic trilobites in peri-reef areas.

\section{Biogeographical links during Cambrian Epoch 3}

During Cambrian Epoch 3, tropically located palaeocontinental masses developed two distinct trilobite faunas: (1) a largely endemic set of polymerids that inhabited warm, shallow-water environments; and (2) a more widespread assemblage of agnostoids, eodiscoids, oryctocephalids and some polymerids that inhabited facies with open ocean access (Robison 1976; Babcock et al. 2007). Many of the polymerids (including paradoxidids, solenopleurids and conocoryphids) were distributed in deeper, presumably cooler, water, shelf and slope facies (Babcock 1994a, b; Robison 1994). A similar pattern continued through the Furongian Epoch, at which time the more widespread trilobite faunas were dominated by agnostoids, ceratopygids and olenids (Taylor \& Cook 1976; Palmer 2005).

Slope and/or cool-water facies of the circum-Pacific region share many common taxa among the agnostoids, eodiscids and oryctocephalids (Palmer 2005). In contrast to the slope and/or cool-water faunas, the predominantly polymerid warmer-water platform faunas show strong provinciality. Trilobites from the Siberian Platform, such as Anomocarina, Chondranomocare, Dinesus, Dorypyge, Kootenia, Ogygopsis, Olenoides and Pseudanomocarina, show biogeographical relations between the Siberian Platform and the Far East, the Altai-Sayan foldbelt, Mongolia, Turkestan, Kazakhstan, China, Avalonia, Precordillera, Gondwana (Taconic Belt, Ossa-Morena, Morocco, Australia, Germany, Antarctica, Montagne Noire, Turkey and Iran), Baltica and Laurentia. Cambrian Series 3 strata of the Siberian platform contain a wide diversity of trilobites, such as Acadagnostus, Dolichagnostus, Goniagnostus, Hypagnostus, Lejopyge, Linguagnostus, Megagnostus, Paradoxides, Peronopsis, Ptychagnostus and anomocarid and oryctocephalid genera. Anopolenus, Eodiscus, Pagetia, Pagetides and Solenopleura are fairly common. Their presence suggests relations with the Altai-Sayan foldbelt, the Baikal area, Turkestan, Kazakhstan, China, Baltica, Laurentia, Avalonia and Gondwana (Australia, Himalaya, Germany, Antarctica, Turkey, and Montagne Noire).

On the SW part of the Siberian Platform, Cambrian Series 2 and the lower half of Series 3 strata exhibit a prevalence of evaporates. Scarce findings, monotony and endemism of trilobites are associated with sedimentation in closed shelf and lagoonal environments (Zharkov 1966, 1970; Yanshin \& Zharkov 1974; Pisarchik et al. 1975; Chechel et al. 1977). The overlying strata (within Series 3 and the Furongian) are composed of argillaceous-carbonate rocks of the subaerial plain and shallow shelf (Zharkov et al. 1982). Endemic redlichioids (Bulaiaspis, Elganellus and Tungusella), ellipsocephalids (Bergeroniaspis) and endemic species of Bathynotus occur in Cambrian Series 2 strata of this zone. Bathynotus is known from coeval deposits in the Altai Sayan foldbelt, China, Australia and Laurentia (Webster 2009). The Toyonian-Amgan boundary, which approximates the boundary between the Cambrian Series 2 and 3, marks a major change in taxonomic composition of the trilobite faunas over the entire
Siberian Platform. This event coincides in time with the beginning of an active sea-level rise and renewed reef building. On the SW side of the Siberian Platform, Proasaphiscus appeared at that time, being distributed also in the Baikal area, Altai-Sayan foldbelt, Kazakhstan, Turkestan and China. Open-sea trilobite assemblages of the upper Guzhangian (upper Cambrian Series 3) and Paibian stages (lower Furongian) show a predominance of agnostoids (Acmarhachis, Ammagnostus, Clavagnostus, Glyptagnostus, Innitagnostus, Lisogoragnostus, Oidalagnostus, Proagnostus and Tomagnostella), although some polymerids (such as Acrocephalites, Aplotaspis, Eugonocare, Onchonotellus, Palaeadotes, Paradamesella and Proceratopyge) were rather common. Their presence shows some biogeographical links with the AltaiSayan foldbelt, Kazakhstan, Turkestan, China, Laurentia, Avalonia, Precordillera, Baltica and Gondwana (Australia, Antarctica, Montagne Noire/Sardinia and Turkey).

Along the western Gondwanan margin, the onset of drastic regressions during Cambrian Epoch 3 exerted control over trilobite diversification and biogeographical connections. Two Epoch 3 trilobite diversifications are recognized: (1) a major migratory radiation of trilobites (a putative recovery fauna following extinction of the redlichiid and olenellid trilobites close to the end of Epoch 2); and, following a major regression, (the middleLanguedocian right: regression, Álvaro et al. 2007), (2) a second trilobite diversification connected with transgressive episodes and representing new migratory appearances of recurrent trilobite genera. The earliest faunal immigration of Epoch 3 is characterized by the stepwise appearance of relatively cosmopolitan trilobites, such as the acrocephalitids, agraulids, conocoryphids, corynexochids, paradoxidids, solenopleurids and agnostoids (condylopygids, phalacromids and spinagnostids). The observed pattern of diversification was not facies-controlled because trilobites appeared in a wide diversity of facies and environments. Subsequently, the western Mediterranean area apparently operated as a centre of evolutionary radiation (or a site of speciation), from which the species were able to spread outwards onto adjacent platforms, in some cases by sympatric speciation (Álvaro \& Vizcaïno 2001). A faunal turnover during a part of the Drumian Stage coincided with a rapid prograding and shoaling (the middle Languedocian regression), which produced widespread areas of coarse-grained sandstones and, therefore, seems to reflect geographically extensive environmental changes. In Baltica there is a regression at the level of the Andrarum Limestone (Nielsen 1996; Axheimer \& Ahlberg 2003), and this is recognized in the southern British Isles and Newfoundland as the 'Andrarum Limestone regression'. Regressive-phase deposits are succeeded by strata of the Lejopyge laevigata Zone (Guzhangian Stage). The subsequent late Languedocian trilobite diversification is well documented in Montagne Noire/Sardinia and Saxo-Thuringia, where it is characterized by an abrupt increase in genera and families. Episodically, off-platform trilobite taxa migrated towards the inner platform. The distributions of taxa were rather strongly controlled by lithofacies differentiation at a time when muddy offshore substrates were established. The level of diversification of new groups during this radiation event was less than in the previous radiation. Dispersal took place to some extent, but the presence of some provincialism suggests that species exchange was selective, and that oceanic areas served as partial barriers to migration. Late Epoch 3 (late Guzhangian) trilobites include typical early Epoch 3 genera such as the conocoryphids, paradoxidids and solenopleurids, which characterize the Acado-Baltic Province (Sdzuy 1972), and new East Gondwanan invaders, such as Abharella, Chelidonocephalus, Derikaspis and Dorypyge (Álvaro et al. 1999).

Avalonian trilobites of Epoch 3 have their closest biogeographical affinities to trilobites of West Gondwana at the end of Cambrian Epoch 2 (or earliest Epoch 3 according to the Moroccan chronostratigraphic chart), but the number of shared taxa declines through Epoch 3 and the Furongian. Avalonian faunas become progressively more similar to Baltic faunas during the 
last two epochs of the Cambrian. The resemblance of the Avalonian and Baltic faunas rests largely on the similarity of their agnostoids and paradoxidoids, and doubtless the relative paucity of peri-Gondwanan agnostoids is a hindrance to inter-regional correlation. Avalonia and Baltica show agnostoid faunas intermediate between those of Laurentia and parts of the Gondwanan margin (Conway-Morris \& Rushton 1988; Álvaro et al. 2003a).

Recent work on Cambrian Epoch 3 faunas of the Himalaya (Jell \& Hughes 1997; Peng et al. 2009) shows a wide variety of agnostoids with a generally cosmopolitan distribution, and polymerids with more regionalized occurrence. Although genera such as Bhargavia and Koldinia suggest links to Laurentia and Siberia, respectively, the Himalayan faunas show the strongest similarity to those of South China and North China, evinced by the shared occurrence of genera such as Kaotaia, Solenoparia and Xingrenaspis. The similarity to Australian faunas is somewhat less pronounced, with many of the forms that occur in both Himalaya and Australia occurring in other regions too. Overall, the Himalayan fauna shows few endemic genera.

\section{Furongian biogeographical links}

A global transgression marks the beginning of the Furongian Epoch. It coincides with the onset of SPICE carbon isotope excursion and extinction of ptychopariid trilobites in Laurentia, as well as some faunal turnovers in other areas such as North and South China (such as the extinction of damasellids). Transgression led to the deposition of dysaerobic to anoxic black shales across the Epoch 3-Furongian transition in Avalonia, Baltica, and Argentina.

In Baltica, biogeographical analysis of trilobites in Łysogóry, Holy Cross Mountains, shows a distinct change in composition of assemblages during the Furongian. Near the beginning of the epoch, faunas were of low diversity and dominated by Avalonian forms. Later, more diversified assemblages appeared, and they are characterized by an increasing number of Baltic elements. This trend was associated with a gradual decrease in the number of endemic species (Żylińska 2001, 2002). It is not clear, however, whether the appearance of non-olenid polymerid trilobites of Avalonian affinity in the Holy Cross Mountains succession is linked to wider-scale events, such as regressions causing extinctions marking the boundaries of Laurentian biomeres. The Furongian succession in Baltica is dominated by olenids and agnostoids, but the series has several levels at which non-olenid polymerids appear. These indicate links with Laurentia and/or Gondwana (Terfelt 2006; Terfelt et al. 2008, 2011; Ahlberg et al. 2009; Żylińska \& Weidner 2012).

Cook \& Taylor (1975) and Taylor \& Cook (1976) presented a palaeogeographical model to explain the occurrence of two types of trilobite assemblages in the Furongian of the Great Basin, USA: one is represented by an allochthonous assemblage containing trilobite taxa typical of the Hungaia fauna, endemic to Laurentia, and the other (Hedinaspis fauna) is characterized by intercontinentally distributed taxa associated with deep water, slope to basinal environments. The Hedinaspis fauna is a Furongian representative of the Jiangnan Province (Kobayashi 1967), but was widespread in latest Cambrian times. Cocks \& Fortey (1982) and Fortey \& Cocks (1992) also emphasized that the profound contrast in faunal composition alone does not indicate geographical separation unless the depositional settings are comparable, whereas the close faunal affinity does not necessarily mean geographical proximity because planktonic and deep-water benthic fauna are widely distributed by crossing the ocean barriers and thus have little value for palaeogeographical reconstruction.

Biogeographical connections between Laurentia and East Gondwana are illustrated by the distribution of the missisquoids.
According to Lee et al. (2008), missisquoid trilobites occurred both in Laurentia and East Gondwana (China, Korea, Thailand, and Australia). Analysis suggests that the missisquoids originated somewhere in Gondwana, most probably in the Sino-Korean block, and expanded their distribution into other Gondwanan areas, and finally into Laurentia during the latest Furongian. The earliest Laurentian missisquoids in deeper-water facies (Ludvigsen \& Westrop 1983) may represent an example of successful initial colonization.

A brief biogeographical summary on the Epoch 3 and Furongian trilobite faunas of Alborz given by Peng et al. (1999) suggests an 'East' Gondwanan affinity of the Iranian fauna, although they also pointed to an inadequate knowledge of Cambrian trilobite faunas. The occurrence of Taoyuania in the late Furongian represents a link with South China and the Karatau-Naryn terrane of Kazakhstan. Late Furongian Mictosaukia is widespread in SW Asia, Afghanistan and Turkey, whereas Alborsella is mostly endemic to Iran and only reported from the Turkish Taurides (Dean 1982).

In the Siberian trilobite assemblages of the Jiangshanian Stage (mid-Furongian), the diplagnostids and olenids (e.g. Pseudagnostus and Parabolina, Plicatolina and Protopeltura) were the most characteristic; others such as Irvingella and Maladioidella are also typical of the stage. Genera such as Acerocare, Lotagnostus, Parabolinites, Plicatolina, Promegalaspides and Trilobagnostus dominated trilobite assemblages of Cambrian Stage 10. The geographical distribution of the listed taxa shows close relationships with Turkestan, Kazakhstan, China, Baltica, Laurentia, Avalonia, the Precordillera and Gondwana (Australia, Antarctica, Montagne Noire/Sardinia, Turkey, Afghanistan, Argentina, Taconic Belt, Cantabro-Iberian basin, Oaxaca and Germany) during the Furongian.

As a result of West Gondwana's poleward drift, Furongian trilobites are relatively rare in the western Mediterranean area. Temperate-water faunas were more abundant and diverse in localized centres of carbonate productivity such as Montagne Noire (Álvaro et al. 2003b), and more impoverished across siliciclasticdominated platforms. The Cantabro-Iberian Basin has yielded Chuangia, Elegantaspis, Langyashania, Maladioidella, Pagodia (Wittekindtia), Parachangshania and Prochuangia, suggesting an East Gondwanan influence (Shergold et al. 1983; Shergold \& Sdzuy 1991). Similar genera have been found in Montagne Noire and Sardinia. They include Abharella, Ammagnostus, Bergeronites, Macropyge, Maladioidella, Micragnostus, Niobella, Onchonotellus, Olentella, Palaeadotes, Paraacidaspis, Probilacunaspis, Proceratopyge, Prochuangia, Shengia and Stigmatoa (Feist \& Courtessole 1984; Loi et al. 1995; Shergold et al. 2000; Álvaro et al. 2007). Together, this assemblage suggests biogeographical relationships with China, Australia and Antarctica (for further discussion of the biogeographical connections between Antarctica, Australia and China, see Lieberman 2004). Finally, only two trilobite genera, Olentella and Seletella, have been documented in Morocco (Destombes \& Feist 1987). Trilobites of the Furongian-Tremadocian transition have also been recorded from the eastern Mediterranean region. In Turkey, Dean et al. (1981, 1993), Shergold \& Sdzuy (1984) and Dean \& Monod (1997) reported Chuangia, Homagnostus, Koldinioidia, Macropyge, Maladioidella, Micragnostus, Niobella, Onchonotellus, Parakoldinioidia, Prochuangia and Pseudagnostus, suggesting biogeographical links with the Franconian Forest area (Germany), Montagne Noire, Bohemia, southern Kazakhstan, southern Siberia, and North and South China. Occurrences of some of these trilobites are succeeded by Alborsella, Pagodia (Wittekindtia) and Mictosaukia, all of which indicate affinities with northern Iran.

The impoverished faunas reported from the Mediterranean region contrast strongly with Avalonian faunas, which contain more than 100 taxa. Of these, the olenids are widely distributed where the appropriate dysaerobic facies are present, and others, such as agnostoids, Cermatops, Proceratopyge (Hughes \& 

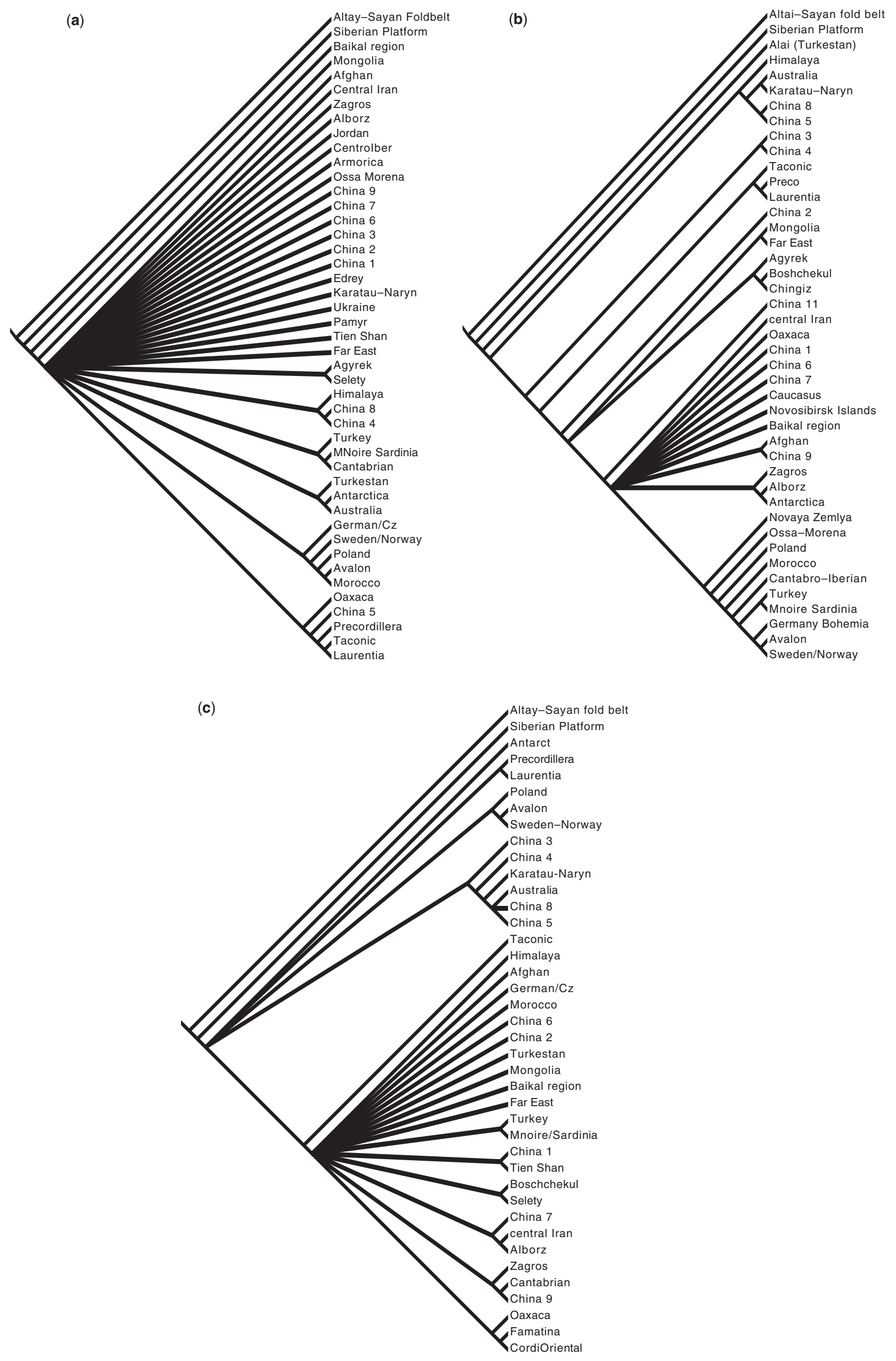

Fig. 19.5. PAE analysis based on the distribution of Cambrian Epoch 2 (a), Cambrian Epoch 3 (b) and Furongian (c) trilobite genera. 
Rushton 1990), other ceratopygoids, Irvingella and Maladioidella (Rushton \& Hughes 1996), are widely distributed in a variety of shelf environments.

A similar situation is reported for Argentina. The latest Furongian trilobites in the Cordillera Oriental are mostly represented by agnostoids and olenids of great biostratigraphical and palaeoecologic significance (Tortello \& Esteban 2003; Waisfeld \& Vaccari 2003; Zeballo \& Tortello 2005; Buatois et al. 2006; Esteban \& Tortello 2007). Trilobite assemblages of the Cordillera Oriental are closely related to those of Bolivia, supporting the palaeogeographical continuity between these peri-Gondwanan regions (Kobayashi 1937; Harrington \& Leanza 1957; Benedetto 2003). Latest Furongian trilobites share strong affinities with Baltica, and have major links with Bolivia, Famatina, Avalonia, Korea and Australia. Harrington \& Leanza (1957) pointed out the faunal similarities between Famatina and the Cordillera Oriental, suggesting that both regions were biogeographically connected. Affinities of their latest Furongian trilobites support the position of the Famatina basin on the margin of Gondwana (Tortello \& Esteban 2007), although they also share strong affinities with Baltica; shared components are present in the Cordillera Oriental, Avalonia, Mexico, Korea and Australia.

\section{Analysis of the worldwide database}

Biofacies patterns and platform-basinal transects have been considered in some margins, such as the Chinese domains (Fig. 19.2). Endemic taxa, mainly based on Jell \& Adrain's (2003) list, were maintained in the dataset. Doubtful generic assignments were first considered and then deleted in successive analyses, and in each analysis the results were similar. When trilobite genera cross Cambrian series boundaries, the taxa are only considered in the series where the oldest species occurred. Three datasets tabulating all the trilobite genera known worldwide are available in the data set. The data compiled by the authors were analysed using a traditional search with TNT version 1.1 (Goloboff et al. 2008) using 10000 replicates with one random seed. The swapping algorithm used a tree bisection reconstruction and 10 trees were saved per replication. Parsimony Analysis of Endemicity (PAE) for Cambrian Epoch 2 included 45 tectonostratigraphical regions for 629 genera; for Cambrian Epoch 3 it included 45 tectonostratigraphical regions for 965 genera; and for the Furongian Epoch it included 40 tectonostratigraphical regions for 866 genera. The results are consensus trees for each for the three Cambrian epochs under analysis. For Epoch 2, the consensus tree is based on the 20 best trees, for Epoch 3 the consensus tree is based on the three best trees, and for the Furongian the consensus tree is based on 80 best trees.

PAE produced distinct area groupings that can be further subdivided into smaller groups (Fig. 19.5):

(1) There is poor resolution associated with Cambrian Epoch 2, where only parts of Siberia are biogeographically distinctive and occur somewhat separated from other tectonostratigraphical units. Some secondary groupings are remarkable in displaying connections between (a) Himalaya, South China and Tarim; (b) Baltica, Avalonia, Morocco, and the distal part of the Mediterranean region (Saxo-Thuringia and Bohemia); and (c) Laurentia, North China and three terranes (Oaxaca, Taconic Belt and Precordillera).

(2) For Cambrian Epoch 3, PAE analysis shows a different configuration: (a) parts of Siberia and the Alai terrane (Turkestan) are still biogeographically distinctive; (b) a second group is formed by the Himalaya, Australia, KaratauNaryn and North and South China; (c) other dispersed groups include the previous Laurentian assemblage without Oaxaca, and an association of the remaining Siberian and Kazakhstan units; (d) an assemblage of remaining East
Gondwanan and Siberian units; and (e) another distinct group represented by the Acado-Baltic Province (Avalonia, Mediterranean region and Baltica).

(3) Finally, the Furongian PAE analysis again shows a slightly different configuration, in which parts of Siberia (Siberian Platform and Altay-Sayan foldbelt) are still biogeographically differentiable from two distinct groups: (a) a Laurentian-Baltic-East Gondwanan basal polytomy that includes Antarctica, a Baltic-Avalonian group, and a collage of Chinese units (including North and South China) associated with Karatau-Naryn and Australia; and (b) the rest of the Gondwanan, Siberian and Kazakhstan units where the westernmost Gondwanan margin is represented by Oaxaca, Famatina and Cordillera Oriental. The Furongian record of broad deposition of dysaerobic to anoxic black shales (throughout Baltica, Avalonia, and the Argentine units) directly affected the taphonomic features and wealth of trilobite assemblages but not their links.

Taking whole faunas into account enables detection of areas of greater similarity than previously assumed. The resulting area groupings achieved with PAE are not consistently similar to biogeographical units previously described. For instance, (1) Siberia shows a mosaic of biogeographical units throughout the Cambrian, in which only the Siberian Platform/Altay-Sayan association is persistent; (2) Karatau-Naryn is a biogeographical unit distinct from the rest of Kazakhstania; (3) North and South China show closer Furongian relationships with the collage formed by Laurentia, Karatau-Naryn, Baltica and Avalonia; and (4) Avalonia offers a gradual modification of West Gondwanan and Baltic affinities, but links with the Furongian westernmost Gondwanan margin (Oaxaca, Famatina and Cordillera Oriental) are not distinct. In addition, the Acado-Baltic province sensu Sdzuy (1972), defined by the presence of solenopleurids, paradoxidids and conocoryphids (Alvaro \& Vizcaïno 2003), is clearly supported by PAE.

The PAE analysis reveals that the distribution of Cambrian palaeobiogeographical units is not primarily controlled by latitude-related thermal gradients, such as Gondwanan subtropical and temperate-water climatic belts. Other factors seem more important, such as palaeogeographical conditions (e.g. migration of centres of carbonate productivity and orogenies), palaeogeographical distances and oceanic circulation patterns, which might have functioned as biogeographical barriers or provided possible migration routes for trilobite exchange between different areas. The development of anoxic substrates and subsequent exceptional preservation of distinct pelagic trilobite families do not show biogeographical implications. However, it is important to recognize that there are various issues associated with the use of PAE, especially regarding the absence of phylogenetic information and the inability to distinguish between vicariance and geodispersal. Therefore, in the future it would be desirable when additional phylogenetic information becomes available to also subject palaeobiogeographical patterns in Cambrian trilobites to other analytical techniques, including modified Brooks parsimony analysis.

\section{Conclusions}

The distribution of 2460 Cambrian genera from $c .40$ worldwide tectonostratigraphical units was used for a quantitative palaeobiogeographical analysis. The dataset was analysed using PAE methods. The analysis resulted in distinct palaeogeographical area groupings of the studied regions. Although there is poor resolution associated with Cambrian Epoch 2, both Epoch 3 and the Furongian offer some distinctive results: (1) the persistence of the Siberian Platform/Altai-Sayan group throughout the Cambrian; (2) a clear differentiation of Karatau-Naryn from other Kazakhstan units, the former displaying biogeographical links with Laurentia and North and South China; and (3) a significant 
change of Baltic/Avalonian affinities, from Mediterranean (Acado-Baltic Province) to Laurentian/North and South Chinese/Antarctic influences. The biogeographical groupings cross equatorial, subtropical and temperate-water climatic belts, as well as broadly distributed Furongian dysoxic-anoxic conditions. Divergences in the distribution of palaeobiogeographical units and Cambrian climatic belts may be due to other factors, such as palaeogeographical conditions and distances, and ocean circulation patterns.

The authors thank the invaluable revisions made by E. Clarkson and S. Peng that have greatly improved a previous version of the manuscript. The database of Cambrian trilobites provided here is meant to assist the tasks of the International Subcommission on Cambrian Stratigraphy. This work is a contribution to projects ANR JC07_194555 from CNRS-USAR and CGL 2010-1941 from MICINNFEDER. N.C.H.'s contribution is supported by the US National Science Foundation grant EAR-053868, M.G.'s contribution is supported by Golestan University, and B.S L.'s contribution is supported by grant DEB-0716162.

\section{References}

Abalos, B., Gil-Ibarguchi, J. L. \& Eguíluz, L. 1991. Cadomian subduction/collision and Variscan transpression in the BadajozCórdoba shear belt, Southwest Spain. Tectonophysics, 199, 51-72.

Ahlberg, P., Axheimer, N., Babcock, L. E., Eriksson, M. E., Schmitz, B. \& Terfelt, F. 2009. Cambrian high-resolution biostratigraphy and carbon isotope chemostratigraphy in Scania, Sweden: first record of the SPICE and DICE excursions in Scandinavia. Lethaia, 42, 2-16.

Álvaro, J. J. \& VizCAÏNo, D. 2001. Evolutionary trends in the ornamentation of Cambrian solenopleuropsine trilobites. Palaeontology, 44, $131-141$.

Álvaro, J. J. \& VizcaÏNo, D. 2003. The conocoryphid biofacies, a benthic assemblage of normal-eyed and blind trilobites. Special Papers in Palaeontology, 70, 127-140.

Álvaro, J. J., Vizcaïno, D. \& Vennin, E. 1999. Trilobite diversity patterns in the Middle Cambrian of southwestern Europe: a comparative study. Palaeogeography, Palaeoclimatology, Palaeoecology, 151, $241-254$.

Álvaro, J. J., Rouchy, J. M. ET AL. 2000. Evaporitic constraints on the southward drifting of the western Gondwana margin during Early Cambrian times. Palaeogeography, Palaeoclimatology, Palaeoecology, 160, 105-122.

Álvaro, J. J., Elicki, O., Geyer, G., Rushton, A. W. A. \& Shergold, J. H. 2003a. Palaeogeographical controls on the Cambrian trilobite immigration and evolutionary patterns reported in the western Gondwana margin. Palaeogeography, Palaeoclimatology, Palaeoecology, $195,5-35$.

Álvaro, J. J., González-Gómez, C. \& Vizcaïno, D. 2003b. Paleogeographic patterns of the Cambrian-Ordovician transition in the southern Montagne Noire (France): preliminary results. Bulletin de la Société géologique de France, 174, 23-31.

Álvaro, J. J., Ferretti, F., González-Gómez, C., Serpagli, E., Tortello, M. F., Vecoli, M. \& Vizcaïno, D. 2007. A review of the Late Cambrian (Furongian) palaeogeography in the western Mediterranean region, NW Gondwana. Earth-Science Reviews, 85, $47-81$.

Álvaro, J. J., Ezzouhairi, H., Ait Ayad, N., Charif, A., Popov, L. \& RibeIRo, M. L. 2008. Short-term episodes of carbonate productivity in a Cambrian uplifted rift shoulder of the Coastal Meseta, Morocco. Gondwana Research, 14, 410-428.

Amireh, B. S., Amaireh, M. N. \& Abed, A. M. 2008. Tectonosedimentary evolution of the Umm Ghaddah Formation (late Ediacaran-early Cambrian) in Jordan. Journal of Asian Earth Sciences, 33, 194-218.

ANonymous 1983. Resolutions of the All-Union Stratigraphic Meeting on the Precambrian, Palaeozoic and Quaternary Systems of Middle Siberia. Part 1 (Upper Precambrian and Lower Palaeozoic). SNIIGG \& MS, Novosibirsk (in Russian), 1-216.

Apollonov, M. K. 2000. Geodynamic evolution of Kazakhstan in the early Palaeozoic (from classic plate-tectonic positions). In:
Bespaev, H. A. (ed.) Geodynamics and Mineralogeny of Kazakhstan. VAC, Alma-Ata, 46-63 (in Russian).

Apollonov, M. K. \& Chugaeva, M. N. 1983. Some trilobites from the Cambrian-Ordovician boundary interval from Batyrbai, Malyi Karatau. In: Apollonov, M. K., Bandaletov, S. M. \& Ivshin, N. K. (eds) Stratigrafiya i paleontologiya nizhnego paleozoya Kazakhstana. Nauka, Alma-Ata, 66-90 (in Russian).

Apollonov, M. K., Chugaeva, M. N. \& Dubinina, S. V. 1984. Trilobites and conodonts from the section of Batyrbay (uppermost Cambrian-lower Ordovician) in the Malyi Karatau. Nauka Kazakh SSR Publishing House, Alma-Ata (in Russian).

Astashkin, V. A., Varlamov, A. I. et AL. 1984. Geology and Oil Perspectives of the Reef System of the Cambrian of the Siberian Platform. Nedra, Moscow (in Russian).

Astashrin, V. A., Peggel, T. V. et al. 1991. The Cambrian System on the Siberian Platform. International Union of Geological Sciences, Herndon, VA, 27, 1-133.

Astashin, V. A., Pegel, T. V. et al. 1995. The Cambrian System of the Foldbelts of Russia and Mongolia. International Union of Geological Sciences, Publications, Moscow, 32, 1-132.

Astini, R. A. 2003. The Ordovician proto-Andean basins. In: BeneDETTO, J. L. (ed.) Ordovician Fossils of Argentina. Secretaría de Ciencia y Tecnología, Universidad Nacional de Córdoba, Cordoba, $1-74$.

Astini, R. A. 2008. Sedimentación, facies, discordancias y evolución paleoambiental durante el Cámbrico-Ordovícico. In: CoIrA, B. \& Zappettini, E. O. (eds) Relatorio del XVII Congreso Geológico Argentino, Geología y Recursos Naturales de la Provincia de Jujuy, Jujuy, 50-73.

Astini, R. A., Benedetto, J. L. \& VacCaRi, N. E. 1995. The Early Paleozoic evolution of the Argentine Precordillera as a Laurentian rifted, drifted, and collided terrane: a geodynamic model. Geological Society of America Bulletin, 107, 253-273.

Astini, R. A., Thomas, W. A. \& Yochelson, E. L. 2004. Salterella in the Argentine Precordillera; an Early Cambrian palaeobiogeographic indicator of Laurentian affinity. Palaeogeography, Palaeoclimatology, Palaeoecology, 213, 125-132.

Axheimer, N. \& Ahlberg, P. 2003. A core drilling through Cambrian strata at Almbacken, Scania, S. Sweden: trilobites and stratigraphical assessment. $G F F, \mathbf{1 2 5}, 139-156$.

Ayala, F. J., Rzhetsky, A. \& Ayala, F. J. 1998. Origin of the metazoan phyla: molecular clocks confirm paleontogical estimates. Proceedings of the National Academy of Sciences USA, 95, 606-611.

Azor, A., Bea, F., González-Lodeiro, F. \& Simancas, J. F. 1994. Geochronological constrains on the evolution of a suture: the OssaMorena/Central Iberian contact. Geologische Rundschau, 84, 375-383.

BABCOCK, L. E. 1994a. Systematics and phylogenetics of polymeroid trilobites from the Henson Gletscher and Kap Stanton formations (Middle Cambrian), North Greenland. Grønlands Geologiske Undersøgelse Bulletin, 169, 79-127.

BABCOCK, L. E. 1994b . Biogeography and biofacies patterns of Middle Cambrian polymeroid trilobites from North Greenland: palaeogeographic and palaeo-oceanographic implications. Grønlands Geologiske Undersøgelse Bulletin, 169, 129-147.

Babcock, L. E., Robison, R. A., Rees, M. N., Peng, S. C. \& Saltzman, M. R. 2007. The Global boundary Stratotype Section and Point (GSSP) of the Drumian Stage (Cambrian) in the Drum Mountains, Utah, USA. Episodes, 30, 85-95.

Bassett, M. G., Popov, L. E. \& Holmer, L. E. 2002. Brachiopods: Cambrian-Tremadoc precursors to Ordovician radiation events. In: Crame, J. A. \& Owen, A. W. (eds) Palaeobiogeography and Biodiversity Change: a Comparison of the Ordovician and MesozoicCenozoic Radiations. Geological Society, London, Special Publications, 194, 13-23.

Benedetto, J. L. 2003. Ordovician Fossils of Argentina. Secretaría de Ciencia y Tecnología, Universidad Nacional de Córdoba, Cordoba, $1-665$.

Bordonaro, W. C., Banchig, A. L., Pratt, B. R. \& Raviolo, M. M. 2008. Trilobite-based biostratigraphic model (biofacies and biozonation) for the Middle Cambrian carbonate platform of the Argentina Precordillera. Geologica Acta, 6, 115-129. 
Boulin, J. 1988. Hercynian Eocimmerian events in Afghanistan and adjoining regions. Tectonophysics, 148, 253-278.

Boulin, J. 1991. Structures in southwest Asia and evolution of the eastern Tethys. Tectonophysics, 196, 211-268.

Brock, G. A., Engelbretsen, M. J. et AL. 2000. Palaeobiogeographic affinities of Australian Cambrian faunas. Memoirs of the Association of Australasian Palaeontologists, 23, 1-61.

Bromham, L., Rambault, A., Fortey, R. A., Cooper, A. \& Penny, D. 1998. Testing the Cambrian explosion hypothesis by using a molecular dating technique. Proceedings of the National Academy of Sciences USA, 95, 12 386-12 389.

Buatois, L. A. \& Mángano, M. G. 2003. Sedimentary facies, depositional evolution of the Upper Cambrian-Lower Ordovician Santa Rosita formation in northwest Argentina. Journal of South American Earth Sciences, 16, 343-363.

Buatois, L. A., Zeballo, F. J., Albanesi, G. L., Ortega, G., Vaccari, N. E. \& MÁngano, M. G. 2006. Depositional environments and stratigraphy of the Cambrian-Tremadocian Santa Rosita Formation at the Alfarcito area, Cordillera Oriental, Argentina: integration of biostratigraphic data within a sequence stratigraphic framework. Latin American Journal of Sedimentology and Basin Analysis, 13, 65-94.

BuRRETT, C. \& RichaRdSON, R. 1980. Trilobite biogeography and Cambrian tectonic models. Tectonophysics, 63, 155-192.

Burrett, C., Long, J. \& Stait, B. 1990. Early-Middle Palaeozoic biogeography of Asian terranes derived from Gondwana. In: McKerrow, W. S. \& Scotese, C. R. (eds) Palaeozoic Palaeogeography and Biogeography. Geological Society, London, Memoir, 12, $163-174$.

Burtman, V. S. 2006. Tien Shan and High Asia. Tectonics and geodynamics in the Palaeozoic. Trudy Geologicheskogo Instituta, 570, $1-214$

Cartwright, P., Haldedahl, S., Hendricks, J. R., Jarrard, R. D., Marques, A. C., Collins, A. G. \& Lieberman, B. S. 2007. Exceptionally preserved jellyfishes from the Middle Cambrian. PLOS ONE, 2, e1121, doi: 10.1371/journal.pone.0001121.

Chang, W. T. 1998. Cambrian biogeography of the Perigondwana faunal realm. Revista Española de Paleontología, special issue, 35-49.

Chechel, E. I., Mashovich, Ya. G. \& Gilev, Yu. G. 1977. Structural Relationships of the Cambrian Saliferous Deposits on the Siberian Platform. Nedra, Moscow (in Russian).

Chen, Y., Xu, B., Zhan, S. \& Li, Y. 2004. First midNeoproterozoic paleomagnetic results from the Tarim Basin (NW China) and their geodynamic implications. Precambrian Research, 133, 271-281.

ChoI, D. K. \& KIM, E. Y. 2006. Occurrence of Changshania (Trilobite, Cambrian) in the Taebaeksan Basin, Korea and its stratigraphic and paleogeographic significance. Palaeogeography, Palaeoclimatology, Palaeoecology, 242, 343-354.

ChoI, D. K., KIm, D. H. \& ShON, J. W. 2001. Trilobite faunal successions across the Cambrian-Ordovician boundary intervals in Korea and their correlation with China and Australia. Journal of Asian Earth Sciences, 21, 781-793.

Chough, S. K., Kwon, S. T., Ree, J. H. \& ChoI, D. K. 2000. Tectonic and sedimentary evolution from the Machari Formation, Yongwol, Korea peninsula - a review and new view. Earth-Science Reviews, 52, $175-235$.

Cluzel, D., Cadet, J. P. \& Lapierre, H. 1990. Geodynamics of the Ogcheon belt (South Korea). Tectonophysics, 183, 41-56.

Cluzel, D., Lee, B. J. \& Cadet, J. P. 1991. Indonesian dextral ductile fault system and synkinematic plutonism in the southwest of the Ogcheon belt (South Korea). Tectonophysics, 194, 161-151.

Cocks, L. R. M. \& Fortey, R. A. 1982. Faunal evidence for oceanic separations in the Paleozoic of Britain. Journal of Geological Society, 139, 465-478.

Cocks, L. R. M. \& ForTey, R. A. 2009. Avalonia: a long-lived terrane in the Lower Palaeozoic? In: Bassett, M. G. (ed.) Early Palaeozoic Peri-Gondwana Terranes: New Insights from Tectonics and Biogeography. Geological Society, London, Special Publications, 325, $141-155$.

Cocks, L. R. M. \& ToRsviK, T. H. 2002. Earth geography from 500 to 400 million years ago: a faunal and palaeomagnetic review. Journal of the Geological Society, London, 159, 631-644.
Cocks, L. R. M. \& TorsviK, T. H. 2005. Baltica from the late Precambrian to mid-Palaeozoic times: the gain and loss of a terrane's identity. Earth-Science Reviews, 72, 39-66.

Conway-Morris, S. \& Rushton, A. W. A. 1988. Precambrian to Tremadoc biotas in the Caledonides. In: Harris, A. L. \& FetTes, D. J. (eds) The Caledonian-Appalachian Orogen. Geological Society, London, Special Publications, 38, 93-109.

CoOK, H. E. \& TAYLOR, M. E. 1975. Early Paleozoic continental margin sedimentation, trilobite biofacies, and the thermocline, western United States. Geology, 3, 559-562.

Courjault-Radé, P., Debrenne, F. \& Gandin, A. 1992. Palaeogeographic and geodynamic evolution of the Gondwana continental margins during the Cambrian. Terra Nova, 4, 657-667.

CowIE, J. W. 1971. Lower Cambrian faunal provinces. Geological Journal, Special Issue, 4, 31-46.

Davidson, E. H., Peterson, K. J. \& Cameron, R. A. 1995. Origin of adult bilaterian body plans: evolution of developmental regulatory mechanisms. Science, 270, 1319-1325.

DEAN, W. T. 1982. The Cambrian-Ordovician transition in south-eastern Turkey and adjacent areas. In: BASSETT, M. G. \& DEAN, W. T. (eds) The Cambrian-Ordovician Boundary: Sections, Fossil Distributions, and Correlations. National Museum of Wales, Cardiff, Geological Series, 3, 87-94.

Dean, W. T. \& Monod, O. 1997. Cambrian Development of the Gondwanaland Margin in Southeastern Turkey. Turkish Association of Petroleum Geology, Ankara, Special Publications, 3, 61-74.

Dean, W. T., Monod, O. \& PerinçeK, D. 1981. Correlation of the Cambrian and Ordovician rocks in southeastern Turkey. Petroleum activities at the 100th year (100 Yilda Petrol Faaliyeti). T.C. Petrol İsleri Genel Müdürlüğ̈̈̈ Dergisi, 25, 269-300.

Dean, W. T., Martin, F., Monod, O., Gül, M. A., BozdoĞan, N. \& ÖzGÜL, N. 1993. Early Palaeozoic evolution of the Gondwanaland margin in the western and central Taurids, Turkey. In: TURGUT, S. (ed.) Tectonics and Hydrocarbon Potential of Anatolia and Surrounding Regions. Ozan Sunğurlu Symposium Proceedings, November 1991, Ankara, 262-272.

Dean, W. T., Monod, O., Rickards, R. B., Osman, D. \& Bultynck, P. 2000. Lower Palaeozoic stratigraphy and palaeontology, KaradereZirze area, Pontus Mountains, northern Turkey. Geological Magazine, 137, 555-582.

Debrenne, F. 1991. Extinction of the Archaeocyatha. Historical Biology, 5, 95-106.

DeCelles, P. G., Gehrels, G. E., Quade, J., Lareau, B. \& Spurlin, M. 2000. Tectonic implications of $\mathrm{U}-\mathrm{Pb}$ zircon ages of the Himalayan orogenic belt in Nepal. Science, 288, 497-499.

Degtyarev, K. \& Ryazantsev, A. 2007. Cambrian arc-continent collision in the Paleozoides of Kazakhstan. Geotectonics, 41, 63-86.

Destombes, J. \& Feist, R. 1987. Decouverte du Cambrien supérieur en Afrique (Anti-Atlas central, Maroc). Comptes Rendus de l'Académie des Sciences, Paris, 304, 719-724.

Dobretsov, N. K., Buslov, M. M., Zhimulev, F. I., Travin, A. V. \& ZAYACHKOVSKY, A. A. 2006. Vendian-Early Ordovician geodynamic evolution and model for exhumation of ultra high- and highpressure rocks from the Kokchetav subduction-collision zone. Geologiya i geofizika, 47, 428-444.

Doré, F. 1994. Cambrian of the Armorican Massif. In: KepPIE, J. D. (ed.) Pre-Mesozoic Geology in France and Related Areas. Springer, Berlin, 136-141.

ENNiH, N. \& LiÉGeoIs, J. P. 2008. The boundaries of the West African craton, with special reference to the basement of the Moroccan metacratonic Anti-Atlas belt. In: ENNIH, N. \& LiÉGEOIs, J. P. (eds) The Boundaries of the West African Craton. Geological Society, London, Special Publications, 297, 1-17.

Ergaliev, G. Кн. 1980. The Middle and Upper Cambrian trilobites of Malyi Karatau. Nauka, Alma-Ata (in Russian).

Ergaliev, G. Кн. 1983. Some Upper Cambrian and Lower Ordovician trilobites from southern Kazakhstan and Ulutau. In: Apollonov, M. K., Bandaletov, S. M. \& Ivshin, N. K. (eds) Stratigrafiya $i$ paleontologiya nizhnego paleozoya Kazakhstana. Nauka, AlmaAta, 35-65 (in Russian).

Ergaliev, G. Kh. \& Ergaliev, F. G. 2008. Middle and Upper Cambrian Agnostida of the Aksai National Geological Reserve, South 
Kazakhstan (Kyrshabakty River, Malyi Karatau Range). Part 1. Gylym, Almaty (in Russian).

Ergaliev, G. KH. \& Pokrovskaya, N. V. 1977. Lower Cambrian Trilobites of the Malyi Karatau Range (South Kazakhstan). Nauka, Alma-Ata (in Russian).

Ergaliev, G. Kh., Zhemchuzhnikov, V., Ergaliev, F. G., Popov, L. E., Ghobadi Pour, M. \& Bassett, M. G. 2008. Trilobite biostratigraphy and biodiversity patterns through the Middle-Upper Cambrian transition in the Kyrshabakty section, Malyi Karatau, southern Kazakhstan. In: RÁBAno, I., Gozalo, R. \& GarcíaBellido, D. (eds) Advances in Trilobite Research. Cuadernos del Museo Geominero, Madrid, 9, 91-98.

Esteban, S. B. \& Tortello, M. F. 2007. Latest Cambrian sedimentary settings and trilobite faunas from the western Cordillera Oriental, Argentina. Memoirs of the Association of Australasian Palaeontologists, 34, 431-460.

Etxebarría, M., Chalot-Prat, F., Apraiz, A. \& Eguíluz, L. 2006. Birth of a volcanic passive margin in Cambrian time: rift paleogeography of the Ossa-Morena Zone, SW Spain. Precambrian Research, 147, 366-386.

Feist, R. \& Courtessole, R. 1984. Découverte du Cambrien supérieur à trilobites de type est-asiatique dans la Montagne Noire (France méridionale). Comptes Rendus de l'Académie des Sciences, Paris, 298, $177-182$.

FInNeY, S. C. 2007. The parautochthonous Gondwanan origin of the Cuyania (greater Precordillera) terrane of Argentine: a re-evaluation of evidence used to support an allochthonous Laurentian origin. Geologica Acta, 5, 127-158.

Fletcher, T. P. \& Rushton, A. W. A. 2007. The Cambrian Fauna of the Leny Limestone, Perthshire, Scotland. Earth and Environmental Science Transactions of the Royal Society of Edinburgh, 98, 199-218 [issued 2008].

Foden, J., Elburg, M. A., Dougherty-Page, J. \& Burtt, A. 2006. The timing and duration of the Delamerian Orogeny: correlation with the Ross Orogen and implications for Gondwana assembly. Journal of Geology, 114, 189-210.

Fortey, R. A. \& Cocks, L. R. M. 1992. The early Palaeozoic of the North Atlantic region as a test case for the use of fossils in continental reconstruction. Tectonophysics, 206, 147-198.

ForTey, R. A. \& Cocks, L. R. M. 2003. Palaeontological evidence bearing on global Ordovician-Silurian continental reconstructions. EarthScience Reviews, 61, 245-307.

Fortey, R. A. \& Rushton, A. W. A. 1976. Chelidonocephalus trilobite fauna from the Cambrian of Iran. Bulletin of the British Museum of Natural History (Geology), 27, 321-340.

Fortey, R. A., Briggs, D. E. G. \& Wills, M. A. 1996. The Cambrian evolutionary 'explosion': decoupling cladogenesis from morphological disparity. Biological Journal of the Linnean Society, 57, 13-33.

Geyer, G. \& Landing, E. 2001. Middle Cambrian of Avalonian Massachussetts: stratigraphy and correlation of the Braintree trilobites. Journal of Paleontology, 75, 116-135.

Geyer, G. \& Palmer, A. R. 1995. Neltneriidae and Holmiidae (Trilobita) from Morocco and the problem of Early Cambrian intercontinental correlation. Journal of Paleontology, 69, 459-474.

Geyer, G., Landing, E. \& Heldmaier, W. 1995. Faunas and depositional environments of the Cambrian of the Moroccan Atlas region. Beringeria, Special Issue, 2, 47-120.

Ghobadi Pour, M. 2006. Early Ordovician (Tremadocian) trilobites from Simeh-Kuh, Eastern Alborz, Iran. In: BAssett, M. G. \& DeISLER, V. K. (eds) Studies in Palaeozoic Palaeontology. National Museum of Wales, Cardiff, Geological Series, 25, 93-118.

Ghobadi Pour, M. \& Popov, L. E. 2009a . First report on the occurrence of Neseuretinus and Ovalocephalus in the Middle Ordovician of Iran. Acta Palaeontologica Polonica, 54, 125-133.

Ghobadi Pour, M. \& Popov, L. E. 2009b . Silicified Middle Cambrian trilobites from Kyrgyzstan. Palaeontology, 52, 1029-1056.

Ghobadi Pour, M., Williams, M., Vannier, J., Meidla, T. \& Popov, L. E. 2006. Ordovician ostracods from east central Iran. Acta Palaeontologica Polonica, 51, 551-560.

Ghobadi Pour, M., Vidal, M. \& Hosseini-Nezhad, M. 2007. An Early Ordovician trilobite assemblage from the Lashkarak Formation, Damghan area, Northern Iran. Geobios, 40, 489-500.
Goloboff, P. A., Farris, J. A. \& Nixon, K. C. 2008. TNT, a free program for phylogenetic analysis. Cladistics, 24, 774-786.

Hairapetian, V., Blom, H. \& Miller, C. G. 2008. Silurian thelodonts from the Niur Formation, central Iran. Acta Palaeontologica Polonica, 53, 85-95.

HajRullina, T. N. 1970. Trilobites of the Mayaian stage of the Turkestan range. In: Shayukuboe, T. S. (ed.) Biostratigrafiya Osadochnykh Obrazovanii Uzbekistana. Nedra, Leningrad, 5-30 (in Russian).

Hajrullina, T. N. 1973. Biostratigraphy and Trilobites of the Middle Cambrian Maiaian Stage from the Turkestan Range. FAN, Tashkent (in Russian).

Hajrullina, T. N. \& Yaskovich, B. V. 1961. New fossils from the Lower Cambrian deposits in the basin of the River Alty-kol. Izvestiva Akademii Nauk Tadzhikskoi SSR, Otdeleniefiziko-matematicheskikh $i$ geologo-khimicheskikh nauk, 2, 111-117 (in Russian).

Harrington, H. J. \& Leanza, A. F. 1957. Ordovician Trilobites of Argentina. University of Kansas Press, Lawrence, KS, Special Publications, 1, 1-276.

HavlíčEK, V., VANeK, J. \& FAtKa, O. 1994. Perunica microcontinent in the Ordovician (its position within the Mediterranean province, series division, benthic and pelagic associations). Sbornik Geologickych $\breve{V} e d$, Geologie, 46, 23-56.

Hendricks, J. R. \& Lieberman, B. S. 2007. Biogeography and the Cambrian radiation of arachnomorph arthropods. Memoirs of the Association of Australasian Palaeontologists, 34, 461-471.

Hodych, J. P., Cox, R. A. \& Kosler, J. 2004. An equatorial Laurentia at 550 Ma confirmed by Grenvillian inherited zircons dated by LAM ICP-MS in the Skinner Cove volcanics of western Newfoundland: implications for inertial interchange true polar wander. Precambrian Research, 129, 93-113.

Holmer, L. E., Popov, L. E., Koneva, S. P. \& Bassett, M. G. 2001. Cambrian-early Ordovician brachiopods from Malyi Karatau, the western Balkhash Region, and northern Tien Shan, Central Asia. Special Papers in Palaeontology, 65, 1-180.

Huang, B., Zhu, R., Otofuji, Y. \& Yang, Z. 2000. The Early Paleozoic paleogeography of the North China block and the other major blocks of China. Chinese Science Bulletin, 45, 1057-1065.

Hughes, N. C. \& JeLl, P. A. 1999. The biostratigraphy and biogeography of Himalayan Cambrian trilobites. In: Macfarlane, A., SorkhaBI, R. B. \& QuAde, J. (eds) Himalaya and Tibet: Mountain Roots to Mountain Tops. Geological Society of America, Boulder, CO, Special Papers, 328, 109-116.

Hughes, N. C. \& Rushton, A. W. A. 1990. Computer-aided restoration of a Late Cambrian ceratopygid trilobite from Wales, and its phylogenetic implications. Palaeontology, 33, 429-445.

Hughes, N. C., Peng, S. C. \& Luo, H. 2002. Kunmingaspis (Trilobita) putatively from the Yunling collage, and the Cambrian history of the eastern Himalayan syntaxial region. Journal of Paleontology, 76, 709-717.

Hughes, N. C., Peng, S. C., Bhargava, O. N., Ahulwalia, A. D., Walia, S., Myrow, P. M. \& Parcha, S. K. 2005. The Cambrian biostratigraphy of the Tal Group, Lesser Himalaya, India, and early Tsanglangpuan (late early Cambrian) trilobites from the Nigali Dhar syncline. Geological Magazine, 142, 57-80.

Hughes, N. C., Myrow, P. M. et AL. 2011. Cambrian rocks and fauna of the Wachi La, Bhutan Mountains, Bhutan. Geological Magazine, 148, 351-379.

Ivshin, N. K. 1953. Middle Cambrian Trilobites of Kazakhstan. Part 1. Akademiya Nauk Kazakhskoi SSR, Alma-Ata, 226pp. (in Russian).

Ivshin, N. K. 1956. Upper Cambrian Trilobites of Kazakhstan, Part 1. Akademiya Nauk Kazakhskoi SSR, Alma-Ata, 98p (in Russian).

Ivshin, N. K. 1957. Middle Cambrian Trilobites of Kazakhstan. Part 2. Akademiya Nauk Kazakhskoi SSR, Alma-Ata, 108pp. (in Russian).

Ivshin, N. K. 1962. Upper Cambrian Trilobites of Kazakhstan, Part 2. Akademiya Nauk Kazakhskoi SSR. Alma-Ata , 412pp. (in Russian).

Ivshin, N. K. 1979. Biostratigraphy and Trilobites of the Lower Cambrian of central Kazakhstan. Nauka Kazakhskoi SSR, Alma-Ata, 126pp. (in Russian).

Jago, J. B., Gum, J. C., Burtt, A. C. \& Haines, P. W. 2003. Stratigraphy of the Kanmantoo Group: a critical element of the Adelaide Fold Belt and Palaeo-Pacific plate margin, Eastern Gondwana. Australian Journal of Earth Sciences, 50, 343-363. 
JELL, P. A. 1974. Faunal provinces and possible planetary reconstructions of the Middle Cambrian. Journal of Geology, 82, 319-350.

JeLL, P. A. \& AdRAIN, J. M. 2003. Available generic names for trilobites. Memoirs of the Queensland Museum, 48, 331-553.

Jell, P. A. \& Hughes, N. C. 1997. Himalayan Cambrian trilobites. Special Papers in Palaeontology, 58, 1-113.

Jiang, G., Christie-Blick, N., Kaufman, A. J., Banerjee, D. M. \& Rai, V. 2003. Carbonate platform growth and cyclicity at a terminal Proterozoic passive margin, Infra Krol Formation and Krol Group, Lesser Himalaya, India. Sedimentology, 50, 921-952.

Khain, V. E. \& Seslavinsky, K. B. 1995. Historical Geotectonics: Paleozoic. Oxford and IBH, New Delhi.

Kheraskova, T. N. 1995. Paleogeography of Central Asia paleoocean in Vendian and Cambrian. In: RodríGuez Alonso, M. D. \& GonZalo Corral, J. C. (eds) XIII Reunión de Geología del Oeste de la Península: Caracterización y evolución de la cuenca neoproterozoicocámbrica en la Península Ibérica, 19-30 September 1995, Salamanca-Coimbra, Salamanca, 77-80.

Khomentovsky, V. V. \& Repina, L. N. 1965. Lower Cambrian of the Siberian Stratotype Section. Nauka, Moscow (in Russian).

KING, W. B. R. 1930. Notes on the Cambrian fauna of Persia. Geological Magazine, 67, 316-327.

KING, W. B. R. 1937. Cambrian trilobites from Iran (Persia). Memoirs of the Geological Survey of India, Palaeontographica Indica, N. S. 22, $\mathbf{5}, 1-22$.

Kirkinskaya, V. N. \& Trunov, V. P. (eds) . 1975. Palaeogeography of Neoproterozoic and Palaeozoic Basins of the Siberian Platform. VNIGRI, Leningrad (in Russian).

KirSCHVINK, J. L., RipPERDAN, R. L. \& Evans, D. A. 1997. Evidence for a large-scale reorganization of Early Cambrian continental masses by Inertial Interchange True Polar Wander. Science, 277, 541-545.

Kobayashi, T. 1937. The Cambro-Ordovician shelly faunas of South America. Journal of the Faculty of Science, Imperial University of Tokyo (Section 2), 4, 369-522.

Kobayashi, T. 1967. The Cambro-Ordovician formations and faunas of South Korea, Part X, stratigraphy of the Chosen group in Korea and South Manchuria and its relation to the Cambro-Ordovician formations of other areas, section $\mathrm{C}$, the Cambrian of eastern Asia and other parts of the continent. Journal of the Faculty of Science, University of Tokyo, 16, 381-534.

KoBAYASHI, T. 1971. The Cambro-Ordovician faunal provinces and their interprovincial correlation. Journal of the Faculty of Sciences, University of Tokyo (Section 12), 18, 129-299.

KoвaYASHI, T. 1972. Three faunal provinces in the early Cambrian period. Proceedings of the Japan Academy, 48, 242-247.

KobaYAShI, T. 1976. Distribution of Cambrian trilobites in the periGondwana seas. Proceedings of the Japan Academy, 52, 187-190.

KoKoulin, M. L. \& RudavsKaya, V. A. (eds) . 1985. Upper Precambrian and Lower Palaeozoic Stratigraphy of the Siberian Platform. VNIGRI, Leningrad (in Russian).

Koneva, S. P. 1979. Stenotecoids and Inarticulate Brachiopods from the Lower and Lower Middle Cambrian of Central Kazakhstan. Nauka, Alma-Ata (in Russian).

Kremenetskiy, I. G. \& Dalmatov, B. A. 1988. New data on the stratigraphy of eastern Transbaikalia: Cambrian, its underlying and overlying strata. Trudy, Institut geologii i geofiziki, Sibirskoe otdelenie, Akademiya nauk SSSR, 720, 83-97 (in Russian).

KumaR, S. \& PANDEY, S. K. 2008. Discovery of trilobite trace fossils from the Nagaur sandstone, the Marwar Supergroup, Dulmera area, Bikaner district, Rajasthan. Current Science, 94, 1081-1085.

KusHAN, B. 1978. Stratigraphy and trilobite fauna of the Mila Formation (Middle Cambrian-Tremadocian) of the Alborz Range, North Iran. Report. Geological Survey of Iran, 46, 1-70.

LANDING, E. 1996. Avalon: insular continent by the latest Precambrian. In: NANCE, R. D. \& Thompson, M. D. (eds) Avalonian and Related Peri-Gondwanan Terranes of the Circum-North Atlantic. Geological Society of America, Boulder, CO, Special Papers, 304, 29-63.

LANDING, E. 2005. Early Palaeozoic Avalon-Gondwana unity: an obituary - response to 'Palaeontological evidence bearing on global Ordovician-Silurian continental reconstructions' by R. A. Fortey and L. R. M. Cocks. Earth-Science Reviews, 69, 169-175.
Landing, E., Peng, S., Babcock, L. E. \& Moczydeowska-Vidal, M. 2007a. Global standard names for the lowermost Cambrian series and stages. Episodes, 30, 283-291.

Landing, E., Westrop, S. R. \& KePPIE, J. D. 2007b. Terminal Cambrian and lowest Ordovician succession of Mexican West Gondwana: biotas and sequence stratigraphy of the Tiñu Formation. Geological Magazine, 144, 909-936.

Lazarenko, N. P. 1982. Correlation of the Cambrian deposits of the Severnaya Zemlya archipelago with the Cambrian deposits of the adjacent territories. The Geology of the Severnaya Zemlya Archipelago, Leningrad: Sevmorgeo, 169-176 (in Russian).

LeE, S. B., LeE, D. C. \& ChOI, D. K. 2008. Cambrian-Ordovician trilobite family Missisquoiidae Hupé, 1955: systematic revision and palaeogeographical considerations based on cladistic analysis. Palaeogeography, Palaeoclimatology, Palaeoecology, 260, 315-341.

Lefebvre, B., Ghobadi Pour, M. \& Nardin, E. 2005. Ordovician echinoderms from the Tabas and Damghan regions, Iran: palaeobiogeographical implications. Bulletin de la Société géologique de France, 176, 231-242.

LI, Z. X. \& Powell, C. Mc. A. 2001. An outline of the palaeogeographic evolution of the Australasian region since the beginning of the Neoproterozoic. Earth-Science Reviews, 53, 237-277.

Lieberman, B. S. 1997. Early Cambrian paleogeography and tectonic history: a biogeographic approach. Geology, 25, 1039-1042.

Lieberman, B. S. 1998. Cladistic analysis of the Early Cambrian olenelloid trilobites. Journal of Paleontology, 72, 59-78.

Lieberman, B. S. 1999. Testing the Darwinian legacy of the Cambrian radiation using trilobite phylogeny and biogeography. Journal of Paleontology, 73, 176-181.

Lieberman, B. S. 2000. Paleobiogeography: Using Fossils to Study Global Change, Plate Tectonics, and Evolution. Kluwer Academic Press/Plenum Publishing, New York.

Lieberman, B. S. 2001. A test of whether rates of speciation were unusually high during the Cambrian radiation. Proceedings of the Royal Society of London, Biological Sciences, 268, 1707-1714.

Lieberman, B. S. 2002a. Phylogenetic analysis of some basal early Cambrian trilobites, the biogeographic origins of Eutrilobita, and the timing of the Cambrian radiation. Paleobiology, 22, 66-79.

Lieberman, B. S. 2002b. Phylogenetic biogeography with and without the fossil record: gauging the effects of extinction and paleontological incompleteness. Palaeogeography, Palaeoclimatology, Palaeoecology, 162, 1-14.

Lieberman, B. S. $2003 a$. Taking the pulse of the Cambrian radiation. Integrated Comparative Biology, 43, 229-237.

Lieberman, B. S. 2003b. Biogeography of the Cambrian radiation: deducing geological processes from trilobite evolution. Special Papers in Palaeontology, 70, 59-72.

LieBERMAN, B. S. 2004. Revised biostratigraphy, systematics, and paleobiogeography of the trilobites from the Middle Cambrian Nelson Limestone, Antarctica. University of Kansas Paleontological Contributions, 14, 1-23.

Lieberman, B. S. \& EldRedge, N. 1996. Trilobite biogeography in the Middle Devonian: geological processes and analytical methods. Paleobiology, 22, 66-79.

Lin, H. L., Zhou, Z. Y., Ni, Y. N. \& Zhou, Z. Q. 1996. Cambrian. In Zhou, Z. Y. \& Dean, W. T. (eds) A Series of Solid Earth Sciences Research in China: Phanerozoic Geology of Northwest China. Science Press, Beijing, 65-70.

Linnemann, U., Gehmlich, M. ET aL. 2000. From Cadomian subduction to Early Palaeozoic rifting: the evolution of Saxo-Thuringia at the margin of Gondwana in the light of single zircon geochronology and basin development (Central European Variscides, Germany). In: Franke, W., HaAk, V., OnCKen, O. \& TANNER, D. (eds) Orogenic Processes: Quantification and Modelling in the Variscan Belt. Geological Society, London, Special Publications, 179, 131-153.

Lisogor, K. A. 1977. Biostratigraphy and trilobites of the Upper Cambrian and Tremadocian of Malyi Karatau (southern Kazakhstan). Trudy Sibirskogo Otdeleniya, Instituta Geologii i Geofiziki Akademii Nauk SSSR, 313, 197-265 (in Russian).

Lisogor, K. A. 2004. Middle Cambrian Trilobites of the Chingiz Range (eastern Kazakhstan). SV-Print, Almaty (in Russian). 
Loi, A., Pillola, G. L. \& Leone, F. 1995. The Cambrian and Early Ordovician of Southwestern Sardinia. In: CHerchi, A. (ed.) Sardinia 95, Sixth Paleobenthos International Symposium, 25-31 October. Rendiconti Seminari Facoltà Scienze Cagliari, 65 (suppl.), 61-81.

Lu, Y. H. 1981. Provincialism, dispersal, development, and phylogeny of trilobites. Geological Society of America, Boulder, CO, Special Papers, 187, 143-151.

Lu, Y. H. \& Lin, H. L. 1989. The Cambrian trilobites of western Zhejiang. Palaeontologica Sinica, New Series B, 25, 1-287.

Lu, Y. H., Chang (Zhang), W. T. eT AL. 1974. Cambrian trilobites. In: Handbook of Stratigraphy and Palaeontology. Science Press, Southwest China, 82-107 (in Chinese).

Lu, Y. H., ZноU, Z. Q. \& ZHоU, Z. Y. 1986. New materials of Onychopyge faunas, with a discussion on the evolution of Onychopyge (Trilobita). Bulletin of the Nanjing Institute of Geology and Palaeontology, Academia Sinica, 7, 69-126 (in Chinese with English summary).

Ludvigsen, R. \& WeStrop, S. R. 1983. Trilobite biofacies of the Cambrian-Ordovician boundary interval of northern North America. Alcheringa, 7, 301-319.

McKerrow, W. S., Scotese, C. R. \& Brasier, M. D. 1992. Early Cambrian continental reconstructions. Journal of the Geological Society, London, 149, 599-606.

Meert, J. G. \& Lieberman, B. S. 2004. A palaeomagnetic and palaeobiogeographic perspective on latest Neoproterozoic and early Cambrian tectonic events. Journal of the Geological Society, London, 161, $1-11$.

Meert, J. G. \& Lieberman, B. S. 2008. The Neoproterozoic assembly of Gondwana and its relationship to the Ediacaran-Cambrian Radiation. Gondwana Research, 14, 5-21.

Mel'nikov, N. V., Astashkin, V. A., Kilina, L. I. \& Shinshkin, B. B. 1989. Paleogeography of the Siberian Platform in the early Cambrian. In: Matukhin, R. G. (ed.) Phanerozoic Paleogeography of Siberia. SNIGGiMS \& MS, Novosibirsk, 10-17.

MetCALFE, I. 1996. Gondwanaland dispersion, Asian accretion and evolution of eastern Tethys. Australian Journal of Earth Sciences, 43, $605-623$.

Mossakovsky, A. A,, Ruzhentsev, S. V., Samygin, S. G. \& KherasKova, T. N. 1993. The Central-Asian fold belt: geodynamic evolution and formation history. Geotectonics, 6, 3-32.

Moya, M. C. 2008. El Paleozoico inferior del noroeste argentino. Evidencias, incógnitas, propuestas para la discusión. In: COIRA, B. \& ZAPPETTINI, E. O. (eds) Relatorio del XVII Congreso Geológico Argentino, Geología y Recursos Naturales de la Provincia de Jujuy, 74-84.

MünKeR, C. \& CoOper, R. A. 1999. The Cambrian arc complex of the Takaka Terrane, New Zealand: an integrated stratigraphical, paleontological and geochemical approach. New Zealand Journal of Geology and Geophysics, 42, 415-445.

MünKeR, C. \& Crawford, A. J. 2000. Cambrian arc evolution along the SE Gondwana active margin: a synthesis from Tasmania-New Zealand-Australia-Antarctica correlations. Tectonics, 19, 415-432.

Myrow, P. M., Hughes, N. C. ET AL. 2003. Integrated tectonostratigraphic reconstruction of the Himalaya and implications for its tectonic reconstruction. Earth and Planetary Science Letters, 212, 433-441.

Myrow, P. M., Hughes, N. C., Searle, M. P., Fanning, C. M., Peng, S. C. \& PARCHA, S. K. 2009. Stratigraphic correlation of Cambrian-Ordovician deposits along the Himalaya: implications for the age and nature of rocks in the Mt. Everest region. Geological Society of America Bulletin, 120, 323-332.

Myrow, P. M., Hughes, N. C. ET AL. 2010. Extraordinary transport and mixing of sediment across Himalayan central Gondwanaland during the Cambrian-Ordovician. Geological Society of America Bulletin, 122, 1660-1670.

NAnce, R. D., Murphy, J. B. et AL. 2008. Neoproterozoic-early Palaeozoic tectonostratigraphic and palaeogeography of the peri-Gondwanan terranes: Amazonian $v$. West African connections. In: ENNIH, N. \& LiÉGeoIs, J. P. (eds) The Boundaries of the West African Craton. Geological Society, London, Special Publications, 297, 345-384.

Natal'in, B. A. \& Şengör, A. M. C. 2005. Late Palaeozoic to Triassic evolution of the Turan and Scythian platforms: the pre-history of the Palaeo-Tethyan closure. Tectonophysics, 404, 175-202.
Nielsen, A. T. 1996. Iltmangel sort slam og trilobiter. Varv, 1, 3-39.

Nielsen, A. T. \& Schovsbo, N. H. 2006. Cambrian to basal Ordovician lithostratigraphy in southern Scandinavia. Bulletin of the Geological Society of Denmark, 53, 47-92.

Okay, A. I., Bozkurt, E., Satir, M., YiĞitbaş, E., Crowley, Q. G. \& Shang, C. K. 2008. Defining the southern margin of Avalonia in the Pontides: geochronological data from the Late Proterozoic and Ordovician granitoids from NW Turkey. Tectonophysics, 461, $252-264$.

Ortega-Gutiérrez, F., Ruiz, J. \& Centeno-García, E. 1995. Oaxaquia, a Proterozoic microcontinent accreted to North America during the late Paleozoic. Geology, 23, 1127-1130.

Palmer, A. R. 1972. Cambrian trilobites. In: Hallam, A. (ed.) Atlas of Palaeobiogeography. Elsevier, Amsterdam, 3-11.

Palmer, A. R. 2005. East-Gondwana/Laurentia trilobite connections what do they tell us? Geosciences Journal, 9, 75-79.

Palmer, A. R. \& Repina, L. N. 1993. Through a glass darkly: taxonomy, phylogeny, and biostratigraphy of the Olenellina. The University of Kansas Paleontological Contributions, New Series, 3, 1-35.

Paterson, J. R. \& Brock, G. A. 2007. Early Cambrian trilobites from Angorichina, Flinders Ranges, South Australia, with a new assemblage from the Pararaia bunyerooensis Zone. Journal of Paleontology, 81, 116-142.

Paterson, J. R., Edgecombe, G. D., García-Bellido, D. C., Jago, J. B. \& Gehling, J. G. 2010. Nektaspid arthropods from the lower Cambrian Emu Bay Shale Lagerstätte, South Australia, with a reassessment of lamellipedian relationships. Palaeontology, 53, $377-402$.

Pegel, T. V. \& Sukhov, S. S. 1996. Towards an integrated biotic and abiotic Cambrian stratigraphy of the Siberian Platform: recent data and perspectives. Abstracts, 30th IGC Meeting, Beijing, 2, 15.

Peng, S. C. 1990. Trilobites from the Panjiazui Formation and the Madaoyu Formation in the Jiangnan Slope Belt. Beringeria, 2, $54-171$.

PENG, S. C. 1992. Upper Cambrian biostratigraphy and trilobite faunas of the Cili-Taoyuan area, north-western Hunan, China. Memoirs of the Association of Australasian Palaeontologists, 13, 1-119.

Peng, S. C. \& BabCock, L. E. 2008. Cambrian Period. In: OGG, J. G., OGG, G. \& Gradstein, F. M. (eds) A Concise Geologic Time Scale. Cambridge University Press, Cambridge, 37-46.

Peng, S. C., Geyer, G. \& Hamdi, B. 1999. Trilobites from the Shahmirzad section, Alborz Mountains, Iran: their taxonomy, biostratigraphy and bearing for international correlation. Beringeria, 25, 3-66.

Peng, S. C., Babcock, L. E., Robison, R. A., Lin, H. L., Rees, M. N. \& SALTZMAN, M. R. 2004. Global standard stratotype-section and point (GSSP) of the Furongian Series and Paibian Stage (Cambrian). Lethaia, 37, 365-379.

Peng, S. C., Hughes, N. C., Heim, N. A., Sell, B. K., Zhu, X., Myrow, P. M. \& Parcha, S. K. 2009. Cambrian trilobites from the Parahio and Zanskar Valleys, Indian Himalaya. Paleontological Society Memoirs (Supplement of Journal of Paleontology), 71, 1-95.

Pereira, M. F., Chichorro, M., Linnemann, U., Eguiluz, L. \& Silva, J. B. 2006. Inherited arc signature in Ediacaran and Early Cambrian basins of the Ossa-Morena Zone (Iberian Massif, Portugal): palaeogeographic link with European and North African Cadomian correlatives. Precambrian Research, 144, 297-315.

Pillola, G. L. 1991. Trilobites du Cambrien inférieur du SW de la Sardaigne, Italie. Palaeontographica Italica, 78, 1-174.

Pillola, G. L. 1993. The Lower Cambrian trilobite Bigotina and allied genera. Palaeontology, 36, 855-881.

PisarchiK, Ya. K., Minaeva, M. A. \& Rusetskaya, G. A. 1975. Paleogeography of the Siberian Platform in the Cambrian. Nedra, Leningrad (in Russian).

Popov, L. E., Bassett, M. G., Zhemchuzhnikov, V. G., Holmer, L. E. \& KLISHEvich, I. A. 2009a. Gondwanan faunal signatures from early Palaeozoic terranes of Kazakhstan and Central Asia: evidence and tectonic implications. In: BAssetT, M. G. (ed.) Early Palaeozoic Peri-Gondwanan Terranes: New Insights from Tectonics and Biogeography. The Geological Society, London, Special Publications, 325, $23-64$.

Popov, L. E., Ghobadi Pour, M., Hosseini, M. \& Holmer, L. E. $2009 b$. Furongian linguliform brachiopods from the Alborz Mountains, Iran. 
Memoirs of the Association of Australasian Palaeontologists, 37, $103-122$.

Pouclet, A., Aarab, A., Fekkak, A. \& Benharref, M. 2007. Geodynamic evolution of the northwestern Paleo-Gondwanan margin in the Moroccan Atlas at the Precambrian-Cambrian boundary. In: LINNEMANn, U., NANCE, R. D., Kraft, P. \& Zulauf, G. (eds) The Evolution of the Rheic Ocean: From Avalonian-Cadomian Active Margin to Alleghenian-Variscan Collision. Geological Society of America, Boulder, CO, Special Papers, 423, 27-60.

Pratt, B. R. \& Waldron, J. W. F. 1991. A Middle Cambrian trilobite faunule from the Meguma Group of Nova Scotia. Canadian Journal of Earth Sciences, 28, 1843-1853.

Ramos, V. A. 2004. Cuyania, an exotic block to Gondwana: review of a historical success and the present problems. Gondwana Research, 7, 1009-1026.

Ree, J. H., Cho, M., Kwon, S. T. \& NaKamura, E. 1996. Possible eastward extension of Chinese collision belt in South Korea; the Imjingang belt. Geology, 16, 895-899.

Repina, L. N. \& Rozanov, A. Yu. (eds). 1992. The Cambrian of Siberia. Nauka, Novosibirsk, 788 (in Russian)

Ribeiro, A., Munhá, J. et aL. 2007. Geodynamic evolution of the SW Europe Variscides. Tectonics, 26, TC6009, doi: 10.1029/ 2006TC002058.

Robardet, M. 2003. The Armorica 'microplate': fact or fiction? Critical review of the concept and contradictory palaeobiogeographical data. Palaeogeography, Palaeoclimatology, Palaeoecology, 195, $125-148$.

Robison, R. A. 1976. Middle Cambrian trilobite biostratigraphy of the Great Basin. Brigham Young University Geology Studies, 23, 93-109.

Robison, R. A. 1994. Agnostoid trilobites from the Henson Gletscher and Kap Stanton formations (Middle Cambrian), North Greenland. Grønlands Geologiske Unders $\phi$ gelse Bulletin, 169, 25-77.

Robison, R. A. \& Pantoja-Alor, J. 1968. Tremadocian trilobites from Nochixtlan region, Oaxaca, Mexico. Journal of Paleontology, 42, 767-800.

Rowland, S. M. \& SHaPIRO, R. S. 2002. Reef patterns and environmental influences in the Cambrian and earliest Ordovician. In: KIESSLING, W., Flügel, E. \& Golonka, J. (eds) Phanerozoic Reef Patterns. SEPM, Tulsa, OK, Special Publications, 72, 95-128.

Rozanov, A. Yu. \& Sokolov, B. S. (eds) 1984. Lower Cambrian Stage Division. Stratigraphy. Nauka, Moscow (in Russian).

Rundevist, D. V. \& Mitrofanov, F. P. (eds) 1993. Precambrian Geology of the USSR. Elsevier, Amsterdam.

Rushton, A. W. A. 1963. Paradoxides from Columbia. Geological Magazine, 100, 255-257.

Rushton, A. W. A. \& Hughes, N. C. 1996. Biometry, systematics and biogeography of the late Cambrian trilobite Maladioidella. Transactions of the Royal Society of Edinburgh, Earth Sciences, 86, 247-256.

Rushton, A. W. A., Cocks, L. R. M. \& Fortey, R. A. 2002. Upper Cambrian trilobites and brachiopods from Severnaya Zemlya, Arctic Russia, and their implications for correlation and biogeography. Geological Magazine, 139, 281-290.

Samson, S., Palmer, A. R., Robison, R. A. \& Secor, D. T., Jr. 1990. Biogeographical significance of Cambrian trilobites from the Carolina slate belt. Geological Society of America Bulletin, 102, $1459-1470$

Sánchez-García, T., Bellido, F. \& Quesada, C. 2003. Geodynamic setting and geochemical signatures of Cambrian-Ordovician rift-related igneous rocks (Ossa-Morena Zone, SW Iberia). Tectonophysics, 365, 233-255.

Sánchez-Zavala, J. L., Centeno-García, E. \& Ortega-Gutiérrez, F. 1999. Review of Paleozoic stratigraphy of México and its role in the Gondwana-Laurentia connections. In: Ramos, V. A. \& KePpIE, J. D. (eds) Laurentia-Gondwana Connections before Pangea. Geological Society of America, Boulder, CO, Special Paper, 336, 211-226.

Santosh, M., Maruyama, S. \& Sato, K. 2009. Anatomy of a Cambrian suture in Gondwana: Pacific-type orogeny in southern India? Gondwana Research, 16, 321-341.

Savitsky, V. E. \& Astashkin, V. A. 1979. Cambrian reef systems of Western Yakutia. International Geology Review, 21, 1117-1126.
Savitsky, V. E., Yevtushenko, V. M., Yegorova, L. I., Kontorovich, A. E. \& Shabanov, Yu. Ya. 1972. The Cambrian of the Siberian Platform (Yudoma-Olenek section type. Kuonamka Assemblage of Sediments). Trudy SNIIGG \& MS, 130. Nedra, Moscow (in Russian).

SCotese, C. \& McKerrow, W. S. 1990. Revised world maps and introduction. In: McKerrow, W. S. \& Scotese, C. R. (eds) Palaeozoic Palaeogeography and Biogeography. Geological Society, London, Memoirs, 12, 1-21.

Scotese, C. R. \& McKerrow, W. S. 1991. Ordovician plate tectonic reconstructions. In: BARNES, C. R. \& Williams, S. H. (eds) Advances in Ordovician Geology. Geological Survey of Canada, Ottawa, Papers, 90, 271-282.

Scotese, C., Boucot, A. J. \& McKerrow, W. S. 1999. Gondwanan palaeogeography and palaeoclimatology. Journal of African Earth Sciences, 28, 99-114.

Sdzuy, K. 1972. Das Kambrium der Acadobaltischen Faunenprovinz Gegenwärtiger Kenntnisstand und Probleme. Zentralblatt für Geologie und Paläontologie (II), 1972, 1-91.

ŞENGöR, A. M. C. 1984. The Cimmeride Orogenic System and the Tectonics of Eurasia. Geological Society of America, Boulder, CO, Special Papers, 195, 1-82.

ŞengöR, A. M. C. \& Natal'IN, B. A. 1996. Paleotectonics of Asia: fragments of a synthesis. In: YIN, A. \& Harrison, M. (eds) The Tectonic Evolution of Asia. Cambridge University Press, Cambridge, 486-640.

Seslavinsky, K. B. \& Maidanskaya, I. V. 2001. Global facies distributions from Late Vendian to Mid-Ordovician. In: ZHURAvlev, A. Yu. \& Riding, R. (eds) The Ecology of the Cambrian Radiation. Columbia University Press, New York, 47-68.

SHERGOLD, J. H. 1975. Late Cambrian and early Ordovician trilobites from the Burke River structural belt, western Queensland, Australia. Bureau of Mineral Resources Bulletin, 153, 1-251.

Shergold, J. H. \& GeYer, G. 2003. The subcommision on Cambrian stratigraphy: the statu quo. Geologica Acta, 1, 5-9.

Shergold, J. H. \& SDZUY, K. 1984. Cambrian and Tremadocian trilobites from Şultan Dag, central Turkey. Senckenbergiana lethaea, 65, $51-135$.

Shergold, J. H. \& SDzuy, K. 1991. Late Cambrian trilobites from the Iberian Mountains, Zaragoza Province, Spain. Beringeria, 4, $193-235$.

Shergold, J. H., Liñán, E. \& Palacios, T. 1983. Late Cambrian trilobites from the Najerilla Formation, North-Eastern Spain. Palaeontology, 26, 71-92.

Shergold, J. H., Feist, R. \& Vizcaïno, D. 2000. Early Late Cambrian trilobites of Australo-Sinian aspect from the Montagne Noire, Southern France. Palaeontology, 43, 599-632.

Simancas, J. F., Azor, A. ET AL. 2009. Tectonic relationships of Southwest Iberia with the allochthons of Northwest Iberia and the Moroccan Variscides. Comptes Rendus Geosciences, 341, 103-113.

St John, J. M. \& BAвсоск, L. E. 1997. Late Middle Cambrian Trilobites of Siberian Aspect from the Farewell Terrane, Southwestern Alaska. US Geological Survey, Reston, VA, Professional Papers, 1574, 269-281.

Sun, X. W. 1996. Sequence stratigraphy, sedimentology, biostratigraphy and palaeontology of the Eastern Warburton Basin (Palaeozoic), South Australia. $P h D$, University of Adelaide.

TAYLOR, M. E. \& CoOK, H. E. 1976. Continental shelf and slope facies in the Upper Cambrian and lowest Ordovician of Nevada. Brigham Young University Geology Studies, 23, 181-214.

Terfelt, F. 2006. Upper middle Cambrian through Furongian of Scandinavia with focus on trilobites, paleoenvironments and correlations. Litholund Theses, 11, 1-21.

Terfelt, F., Eriksson, M. E., Ahlberg, P. \& Babcock, L. E. 2008. Furongian (Cambrian) biostratigraphy of Scandinavia - a revision. Norwegian Journal of Geology, 88, 73-87.

Terfelt, F., Ahlberg, P. \& Eriksson, M. E. 2011. Complete record of Furongian polymerid trilobites and agnostoids of Scandinavia a biostratigraphical scheme. Lethaia, 44, 8-14, doi: 10.1111/j. 1502-3931.2009.00211.x.

THEOKRITOFF, G. 1979. Early Cambrian provincialism and biogeographic boundaries in the North-Atlantic region. Lethaia, 12, 281-295.

Tkachenko, V. I., Ushatinskaya, G. T., Zhuravlev, A. Yu. \& Repina, L. N. 1987. Cambrian sediments of the Kolyma Uplift. 
Izvestiya Akademii nauk SSSR, Seriya geologicheskaya, 8, 55-62 (in Russian).

ToRsviK, T. H. \& Rehnström, E. F. 2001. Cambrian palaeomagnetic data from Baltica: implications for true polar wander and Cambrian palaeogeography. Journal of the Geological Society, London, 158, $321-330$.

TorsviK, T. H., SMethurst, M. A. et AL. 1996. Continental break-up and collision in the Neoproterozoic and Palaeozoic - a tale of Baltica and Laurentia. Earth-Science Reviews, 40, 229-258.

Torsvik, T. H., Paulsen, T. S., Hughes, N. C., Myrow, P. M. \& GANERøD, M. 2009. The Tethyan Himalaya: palaeogeographical and tectonic constraints from Ordovician palaeomagnetic data. Journal of the Geological Society, London, 166, 679-687.

Tortello, M. F. \& Esteban, S. B. 2003. Trilobites del Cámbrico Tardío de la Formación Lampazar (sierra de Cajas, Jujuy, Argentina). Implicancias bioestratigráficas y paleoambientales. Ameghiniana, 40, $323-344$.

Tortello, M. F. \& Esteban, S. B. 2007. Trilobites de la Formación Volcancito (Miembro Filo Azul, Cámbrico Tardío) del Sistema de Famatina, La Rioja, Argentina: aspectos sistemáticos y paleoambientales. Ameghiniana, 44, 597-620.

Troedsson, G. T. 1937. On the Cambro-Ordovician faunas of western Qurugtagh, eastern Tien Shan. Palaeontologica Sinica, New Series, B, $1-74$.

Vaughan, A. P. M. \& Pankhurst, R. J. 2008. Tectonic overview of the West Gondwana margin. Gondwana Research, 13, 150-162.

Veevers, J. J., Walter, M. R. \& ScheibNer, E. 1997. Neoproterozoic tectonics of Australia-Antarctica and Laurentia and the $560 \mathrm{Ma}$ birth of the Pacific Ocean reflect the 400 m.y. Pangean supercycle. Journal of Geology, 105, 225-232.

Waisfeld, B. G. \& Vaccari, N. E. 2003. Trilobites. In: Benedetto, J. L. (ed.) Ordovician Fossils of Argentina. Secretaría de Ciencia y Tecnología. Universidad Nacional de Córdoba, Cordoba, 295-410.

Wang, D. Y. C., Kumar, S. \& Hedges, S. B. 1999. Divergence time estimates for the early history of animal phyla and the origin of plants, animals and fungi. Proceedings of the Royal Society of London, Series B, Biological Sciences, 266, 163-171.

WeBster, M. 2009. Systematic revision of the Cambrian trilobite Bathynotus Hall, 1860, with documentation of new occurrences in western Laurentia and implications for intercontinental biostratigraphic correlation. Memoirs of the Association of Australasian Palaeontologists, 37, 369-406.

Williams, M., Siveter, D. J., Popov, L. E. \& Vannier, J. M. C. 2007. Biogeography and affinities of the bradoriid arthropods: cosmopolitan microbenthos of the Cambrian seas. Palaeogeography, Palaeoclimatology, Palaeoecology, 248, 202-232.

Windley, B. F., Alexeiev, D., Wenjiao, X., Kroner, A. K. D. \& BADARCH, G. 2007. Tectonic models for accretion of the Central Asian Orogenic Belt. Journal of the Geological Society, London, 164, 31-47.

WitTKe, H. W. 1984. Middle and Upper Cambrian trilobites from Iran: their taxonomy, stratigraphy and significance. Palaeontographica, Abteilung A, 183, 91-161.

Wolfart, R. 1974a. Die Fauna (Brachiopoda, Mollusca, Trilobita) aus dem Unter-Kambrium von Kerman, Südost-Iran. Geologisches Jahrbuch, Reihe B, 8, 5-70.

Wolfart, R. 1974b. Die Fauna (Brachiopoda, Mollusca, Trilobita) des älteren Ober-Kambriums (Ober-Kushanian) von Dorah Shah Dad, Südost-Iran, und Surkh Bum, Zentral-Afghanistan. Geologisches Jahrbuch, Reihe B, 8, 71-184.

Wolfart, R. \& Kursten, M. 1974. Stratigraphie und Paläogeographie des Kambriums in mittleren Süd-Asien (Iran bis Nord-Indien). Geologisches Jahrbuch, 8, 185-234.

Wolfart, R. \& WitteKInDT, H. 1980. Geologie von Afghanistan. Gebrüder Borntraeger, Berlin.

Wray, G. A., Levinton, J. S. \& Shapiro, L. H. 1996. Molecular evidence for deep Precambrian divergences among Metazoan phyla. Science, 274, 568-573.
YANG, J. L. 1988. Cambrian. In: YIN, H. F. (ed.) Paleobiogeographgy of China. Chinese University of Geosciences Press, Wuhan (in Chinese).

Yanshin, A. L. \& Zharkov, M. A. (eds) 1974. Geology and Potassium Content of the Cambrian on the Southwestern Siberian Platform. Nauka, Novosibirsk, 1-412 (in Russian).

YASKovich, B. V. \& Repina, L. N. (eds) 1975. Stratigraphy and fauna of the Lower Palaeozoic of the northern foothills of Turkestan and Alai Ridges (southern Tien Shan). Trudy Instituta Geologii i Geofiziki, 278, 1-351 (in Russian).

YIN, A. \& NIE, S. Y. 1993. An indentation model for the North and South China collision and development of the Tan-Lu and Honam fault systems, eastern Asia. Tectonics, 12, 801-813.

Zeballo, F. J. \& Tortello, M. F. 2005. Trilobites del Cámbrico Tardío-Ordovícico Temprano del área de Alfarcito, Tilcara, Cordillera Oriental de Jujuy, Argentina. Ameghiniana, 42, 127-142.

ZHANG, W. T. 1989. World Cambrian biogeography. Chinese Academy of Sciences. Contribution to the 28th International Geological Congress, 1989, Washington, DC, 209-220.

Zhang, W. T. 2003. Cambrian correlation between North America and China based on trilobite and conodont faunas. Acta Palaeontologica Sinica, 42, 305-316.

Zhang, W. T. 2006. Problems of Cambrian trilobite biogeography. EarthScience Frontiers, 13, 139-144.

Zhang, W. T., Lu, Y. H., Zhu, Z. Y., Zhang, S. G. \& Yuan, J. L. 1980. Cambrian trilobite faunas of southwestern China. Palaeontologica Sinica, new series B, 16, 1-497 (in Chinese with English summary).

Zhao, C. J., Peng, Y. J. eT AL. 1996. Structure Framework of East Part of both Jiling and Heilongjiang Provinces and their Crustal Evolution. Liaoning University Press, Shenyiang (in Chinese).

Zharkov, M. A. 1966. Cambrian salt-bearing formation of the Siberian Platform. Sovetskaya Geologiya, 2, 32-45.

Zharkov, M. A. 1970. Formation conditions of saliferous Siberian strata and their potassium potential. The State and Tasks of Soviet Lithology. Nauka, Moscow, 3, 40-48.

Zharkov, M. A., Mashovich, Ya. G. \& Chechel, E. I. 1982. Interrelation of saliferous formation and the overlying red-coloured Cambrian formation on the southern Siberian Platform. Nauka, Novosibirsk (in Russian).

ZноU, Z. L. 1982. Early Palaeozoic trilobites from eastern Xizang and western Sichuan. In: Stratigraphy and Paleontology in W Sichuan and E Xizang (2). People's Publishing House of Sichuan, Chengdu, 293-299 (in Chinese with English abstract).

Zhou, Z. Y. \& Zhen, Y. Y. (eds) 2008. Trilobite Record of China. Science Press, Beijing.

Zhou, Z. Y., Lin, H. G. \& NI, Y. N. 1996. Early Palaeozoic plate tectonics and geological evolution. In: ZHOU, Z. Y. \& DeAN, W. T. (eds) A Series of Solid Earth Sciences Research in China: Phanerozoic Geology of Northwest China. Science Press, Beijing, 3-21.

Zhou, Z. Y., Zhen, Y. Y. \& Peng, S. C. 2008. A review of Cambrian biogeography of China. Cuadernos del Museo Geominero, 9, 435-442.

ŻyLińsKA, A. 2001. Late Cambrian trilobites from the Holy Cross Mountains, central Poland. Acta Geologica Polonica, 51, 333-383.

ŻYLIŃSKA, A. 2002. Stratigraphic and biogeographic significance of Late Cambrian trilobites from Łysogóry (Holy Cross Mountains, central Poland). Acta Geologica Polonica, 52, 217-238.

ŻylińsKa, A. 2013. The oldest Cambrian trilobites from the Holy Cross Mountains, Poland: taxonomic, stratigraphic and biogeographic reappraisal. Acta Geological Polonica, 63, 57-87.

ŻyLIŃSKA, A. \& SZCZEPANIK, Z. 2009. Trilobite and acritarch assemblages from the Lower-Middle Cambrian boundary interval in the Holy Cross Mountains (Poland). Acta Geologica Polonica, 59, $413-458$.

ŻylińsKa, A. \& Weidner, Y. 2012. Guests or residents? Non-olenid trilobites from the uppermost Cambrian Series 3 and lower Furongian of Sweden. Journal of Guizhou University (Natural Science), 29 (Supplement 1), 198. 